九州大学学術情報リポジトリ

Kyushu University Institutional Repository

\title{
On The Affinity of The Cultivated Varieties of Rice Plants, Oryza Sativa L
}

Kato, Shigemoto

Institute of Agronomy, Kyushu Imperial University

https://doi.org/10.5109/22556

出版情報 : 九州大学大学院農学研究院紀要. 2 (9), pp. 241-276, 1930-02. Kyushu Imperial University バージョン：

権利関係: 
Jornal of the Bepartment of Agriculture, Kynshu Imperial University, V.1. 2, No. o. February $25,1930$.

\title{
ON THE AFIINITY OF THE CULTIVATED VARHETES OF RICE PLANTS, ORI\%A SATIL L'
}

\author{
Shigemoto KA'O \\ In onllakmation with: I Iirosi kissks, Shirrku IIAk, \\ Soslin, Makuyame and Yoshisuke Taktgum
}

\section{CONTENTS}

1. Int roduction

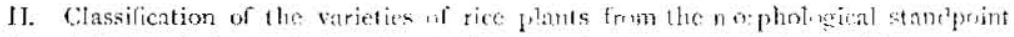

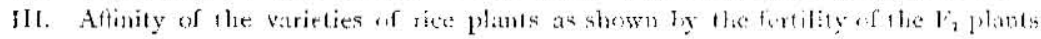

r. Mothols of imestigation

2. lixperimental resulis

1) Result of preliniarary investigration on the parent pilants

a) Fertibity of the $F$, plituts within the state type and of the between the different types

3) Thesree of fertibity of the $k_{2}$ plants

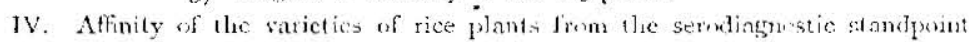

I. Methods of investigation

2. Experimental results

I) Results of investigation on the errasecs tesed fir comp parative study

2) Resultis of investigation on the rice plants

V. Atfinity of the varictios of rice plants, viewed from (be cytringical stimdpuint

I. Methods of investigation

2. Experimental results

1) Pinlen formation in the $F$, plants

a) Results of cylotingical sesearch

V1. Gencral consideration and cronclusion

VII. Sunmary

Literature

1 Contributions from the Institute of Agromony, Kyıshu Inperial University, No. 2s. 


\section{INTRODLCTION}

In the study of the relationships of various types of plants, some scientists $(4,8$, I $2,15,20,2 \mathrm{I}$ etc.) have attempted to take advantage of the serodiagnostic characters of plant proteins. However, it is well known, that the fertility of hybrid plants is higher or lower according as the parent plants are more or less closely allied $(1,3,6,9,19$ etc.). Indeed, in the case when the parents are very distantly allied, the hybrids often show sterility, and it is a matter of common knowledge that in such a cise the fomation of pillen in the IF plants becomes very abnumal. Cytological investigations have shown that the abnormality of pollen formation in the $F$, plants is due either to the disharmony of their respective chrmosomes, of to the difference of physiological processes of pollen formation from the pollen wother-cell $(5,7,10 \mathrm{etc}$ ). If the above may be recognized as a general fact prevailing in the vegetable kingdom, the clegree of affinity of certain plants may be dedaced from a serodiagnostic investigation of them, an examination of the degree of fertility of their $I i_{1}$ plants, or a cytological investigation of their pollen formation. Tscmiran (19), for instance, has already observer that the degree of fertility of the $\mathrm{J}$, plants is fairly in accorlance with the systematic relationship of the genus friticum, which Zane, (21) has serodiagnostically and Schulz (IS) morphologically elucidated.

If we consider the manner of classification of cultivated rice plants in use by many agronomists (II, 13 etc.), we slatl find that all of them are based solcly on the plant form, the characters which appear during cultivation, the use, or the morphological differences. These methois do not, however, take into consideration the facts concerning their affinity. This being the case, the authors collected during the last few years cultivated varieties of rice from the chicf rice producing regions of the world. Then, wishing to find out their affinity, they attempted, firstly, a classification of varieties from the morphological standpoint; secondly, they carried out experiments on the fertility of their hybrid plants; thirdly, they malc a cytological as well as a serodiagnostic investgation; and fouthly, they examined whether the results of the study of the affinity based upon the second and third methods above mentioned were in accord with those as icducer from the morphological character of the plants. It was establisted that, on the whole, they are in accord. Further, the relationships determined by 
means of the hybridization experiment (9) were nearly in accord with those determined by serodiagnostic investigation $(8)$ nearly for the same material; and again the cytological inquiry confirmed the above results.

\section{J. CLASSITICATION OF TIIE VARIYITHS OF RICE PLANTS FROM \\ IIII: MORPHOROGICA, STANJ)MIN1}

The material used for the experiments consisted of glutinous, nonglutinous, scented, red, or long-glumed varieties of lowland and upland rice, collected from Japan Proper, Korea, Formosa, China, Java, India, Hawiii, the United States, etc., in 1923, and cultivated in the College of Agriculture in the Inperial University of Kyushu. Of these, about IOO representative varieties were used for the experiments.

A close scrutiny of every character of these varieties from the morphological standpoint shows that the characters of the plants are extrencly varicd; more particularly, I) the shape and color of the leaf, 2) the angle formed by the uppemost leaf and the stem, 3) the shrpe of the grain, 4) the presence or absence of the awn, or its amount when present, 5) the lengtly and amount of hairs on the glume, etc. The characteristics have been made the main points of classification, by means of which the rice varieties my he grouped under two types, one of which the authors have named "Japonica" aml the other "Indica." The differentiating morphological features of these types may be summed up as follows:

Differentiating features

Charaters

1) Shape and colser of the
Jeaf:

2) Angle formed by the up permost han and the stem:

3) Frrnse of grains: 
4) I'resence or absence of the awn, or its degree when present:

5) Length and amount of hairs on the glume:
Various gradations from longawned it, awnless.

I tairs are thick and comparatively long.
A large majority are awnless; though awnel varicties are selelem met with, when met their awns are short.

Compered with the varietics. belonging to the "Japonica" type, hairs are ilin and sliort.

Table I

Classification of the varieties of rice plants from the norphological stindpint

\begin{tabular}{|c|c|c|c|}
\hline \multicolumn{2}{|c|}{ Varieties of the "Japonica" type } & \multicolumn{2}{|c|}{ Varieties of the "Indica" type } \\
\hline Naunc & Native place & Name & Native place \\
\hline Wasc-Shinriki (早生科力) & Japan & Tran-koffo-ira（矰鹿北螦） & Fonnosia \\
\hline Nakate-Shinrilsi (性䑚力) & $"$ & Sui-yu (清测) & $\because$ \\
\hline Okute-Shinriki (晦件神力) & " & 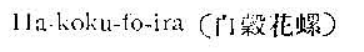 & " \\
\hline Omachi (雄时) & " & 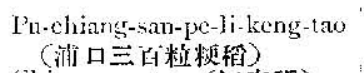 & China \\
\hline Aikoku（愛國） & $"$ & Clinng-nan tao (江南筧) & " \\
\hline 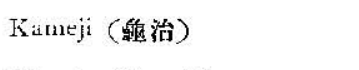 & " & $\begin{array}{l}\text { Chan-shou-sien-tao } \\
\text { (管敉和稳) }\end{array}$ & " \\
\hline Minode $(\mathrm{H} / \mathrm{H})$ & , & Pa-shih-jih-sien (八十日种) & $\because$ \\
\hline 1 fimmato (Пノ本) & $"$ & 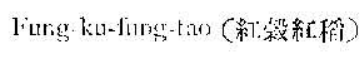 & China \\
\hline 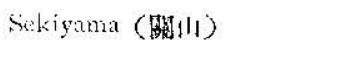 & $"$ & 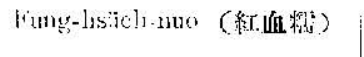 & Chima \\
\hline 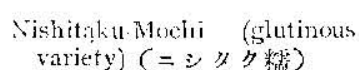 & $"$ & I Wuan-sien (放南悡) & $\Rightarrow$ \\
\hline 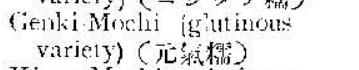 & " & 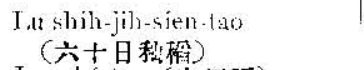 & (Clina \\
\hline 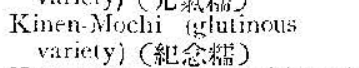 & $"$ & 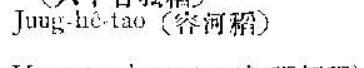 & (kinansta) \\
\hline Kutomoro red variety)(热諸) & " & 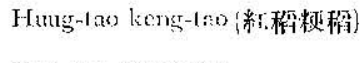 & (Chickians) \\
\hline $\begin{array}{l}\text { Choofeito (Jong-glumed variely) } \\
\text { (長頴枌) }\end{array}$ & " & Ya-i tao (獭央稻) & $, " 1,3$ \\
\hline 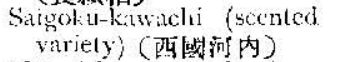 & " & 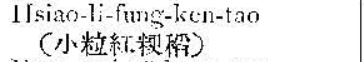 & $" \quad$ i, \\
\hline 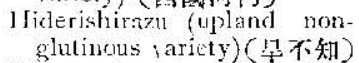 & ". & 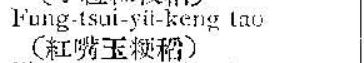 & $\begin{array}{l}\text { China } \\
\text { (Stech-wan) }\end{array}$ \\
\hline $\begin{array}{l}\text { Tianasari (upland non gluti- } \\
\text { nous varjety) (田传) }\end{array}$ & $"$ & 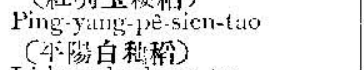 & $\begin{array}{l}\text { Chima } \\
\text { (Clickians) }\end{array}$ \\
\hline $\begin{array}{l}\text { Gifu Mocli (upland glutinous } \\
\text { variety) (岐㚖精) }\end{array}$ & $"$ & 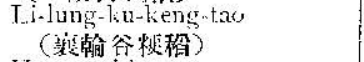 & $" 1, \quad)$ \\
\hline Tataso (多々利) & Korea & $\begin{array}{l}\text { Huang-pi-keng-lao } \\
\text { (药皮数幍) }\end{array}$ & 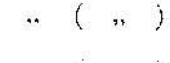 \\
\hline $\begin{array}{l}\text { Salpei (growing wild) } \\
(\forall ル ヘ ゚-)\end{array}$ & $"$ & 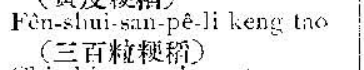 & $\because \quad(\quad, \quad)$ \\
\hline Seiso (晴私) & ", & $\begin{array}{l}\text { Chi-ching tio-keng tao } \\
\text { (苏莖榴梗稻) }\end{array}$ & $" \quad(\cdot, \quad)$ \\
\hline
\end{tabular}




\begin{tabular}{|c|c|c|c|}
\hline (hang slome-lun-mi & Chima & 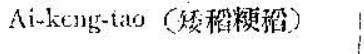 & $\begin{array}{l}\text { China } \\
\text { (Chekiasug) }\end{array}$ \\
\hline $\begin{array}{l}\text { (han -shou-wan tao } \\
\text { (常海唤稳) }\end{array}$ & " & $\begin{array}{l}\text { Mang ku-keng-tao } \\
\text { (艺频粳葐) }\end{array}$ & $"(, j$ \\
\hline 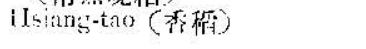 & ," & 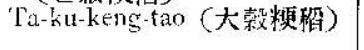 & $"(")$, \\
\hline 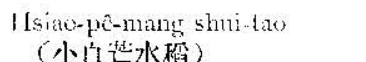 & " (Chili) & 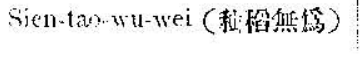 & $\begin{array}{l}\text { China } \\
\text { (Kiangsu) }\end{array}$ \\
\hline 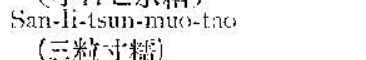 & China & Yang-sicn-1ao（洋和稳） & $"(n)$ \\
\hline 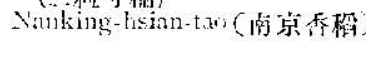 & China & Tao-jcra-chino（道人檥） & China \\
\hline Clans li (長精) & $\begin{array}{c}\text { Clibia } \\
\text { (Whelang) }\end{array}$ & Chiang-nanlano (江南稳) & $\begin{array}{l}\text { China } \\
\text { (Anwhei) }\end{array}$ \\
\hline Keng-taio（被积i) & $\begin{array}{l}\text { \{hinat } \\
\text { (Changchow) }\end{array}$ & 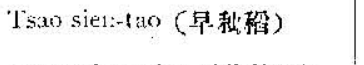 & $\begin{array}{l}\text { Chira } \\
\text { (Tonan Univ) }\end{array}$ \\
\hline 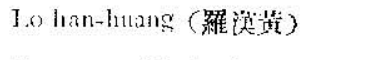 & $\begin{array}{l}\text { China } \\
\text { (Wianssu) }\end{array}$ & Huang-k:1n-sien（溃幹秘） & $\# 5 \quad(, y)$ \\
\hline 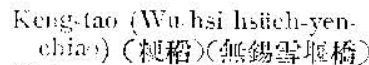 & $"(")$, & 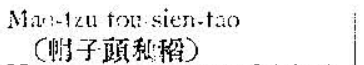 & $"()$, \\
\hline 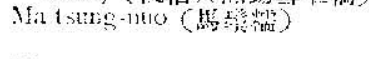 & Clinu & 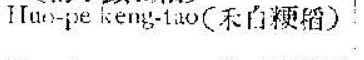 & (Chekiang) \\
\hline 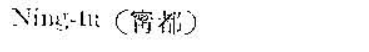 & $"$ & 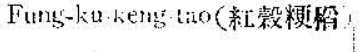 & $\Rightarrow \quad(\quad)$ \\
\hline 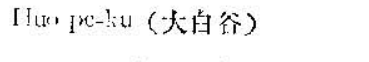 & $"$ & 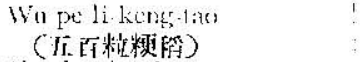 & $"(\Rightarrow)$ \\
\hline 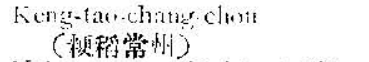 & $"$ & 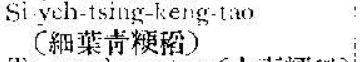 & $"(\quad, \quad)$ \\
\hline 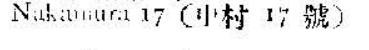 & lurmesil & 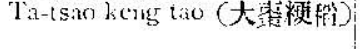 & $"(n)$ \\
\hline Hawaii no $15^{\circ 3}$ & 1l:tw.iii & 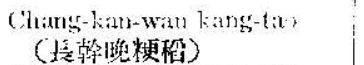 & Chima \\
\hline Jiurtana & $U \therefore A$. & 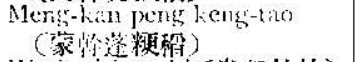 & , \\
\hline lon lentma & " & Wu-ku jxi.nt-clis ( & Fotinersil \\
\hline Ifoniduras & $"$ & Veilisenalti & Jaty:i \\
\hline Prace no. 6 & " & Gangasale follatta & $\begin{array}{l}\text { Somptern } \\
\text { incliat }\end{array}$ \\
\hline Kintele & Tratzit & Recl liangon & Western India \\
\hline Amareria & "' & Seenaddy & Ceylons \\
\hline \multirow[t]{6}{*}{ Turank: } & " & Karalfit cheenatti & " \\
\hline & & Hawaii no. 17 & Hawaii \\
\hline & & Carolina Gold & U.S. \\
\hline & & Hatardavi & Coylon \\
\hline & & Basmiti & India \\
\hline & & Black Seenadkly & Ceylon \\
\hline
\end{tabular}

The classification of the varieties accorling to the morphological method has shown that the varieties native to Japan Proper, Korea, and Northern China belong to the "Japonica" type without a single ex- 
ception; that those native to Southern China, Formosa, Java, India, Ceylon, etc. belong, as a rule, to the "Indica" type; and that some varictics in Central China, I Iawai, 1le United States of America, Braril, etc. belong either to the "Japonica" or to the "Indica" type (sce Table I). The Tan-kofo-ina, native to Formosil, closely resembling the I Innan-sien, belongs to the "Indica" type and yet the roundish shape of its grain reminds one somewhat of the "Japonica" type.

111. AFFINITY OF THE VMRLELIES OF RICE PLANTS AS SHOWN

BY THE FERTLITY OF THE $F_{1}$ PIANTS

J. Methods of investigation

For investigating the fertility of hybric plants, a great number of the cultivated varieties of rice plant used in the aforesaid morphological study was employed. Special carc was taken in these experinent concerning the following 12 varieties: 1) Wasc-Shinrili, 2) TalateShinrili, 3) Sekiyama, 4) Onachi, 5) Hiderishirazu, 6) Tataso, 7) Salpei 8) Chang-shou-shên-mi, 9) Clang-shou-wan-tao, and 10) Isicing-tao (all belonging to "Japonica" type); 1 I) JTunan-sion and 1 2) Tan-korfo-ira (the latter two belong to "Indica" type). The F, plants werc obtained by atificial crussing, fircty between several varieties belonging cither to the "Japonica" or the "Indica" type (hybriclization witlin the same type) and scondly between those of the "Japonica" and the "Intica" type (hybriclization between the different types). All seeds of the If, plants were sown at the same time with the parent scecls, in the following year, under similar conditions. These plants were partly allowed to flower and bear seeds, while spikes of sone plants which were covered with paraffin paper bags during the blooning period to prevent their natural hybridization, were studicd at maturity as to the fertility of their spikes. Though the authors thus investigated the degree of the fertility of the $F_{1}$ plants, they have kept further the $F_{s}$ plants, mainly the hytribls between the different types, under cultivation and examined the segregation of the degrecs of their fertility. The method of self-fertilizition and the investigation of fertility in this case was the same as in that of the $F_{1}$.

The authors distinguished between fertile and sterile scecis with the naked eye; and for the purpose of indicating the degree of fertility 
of each individual plant, they examined in the flowering periods to calms for cach plant, which have tillered comparatively early, whether the spikes had been covered or left uncovercd, and the degree of the fertility of the plant in cuestion was indicated by the percentage of fertilc sceds against the total. As the difference of fertility betwcen those plants of which the spikes had been covered and those left uncovered was always very insignificant, they took the average of both to indicate the degree of fertility.

\section{Experimental results}

1) Results of prelininary investigation on the parent plants

When the authors, on investigating the fertility of the principal varieties cultivated in the agricultural experimental farm of the Imperial University of Kyushu, used for hybridization the above named I 2 varicties, including the varicties belonging to two different types, they found that those plants whose spikes had been covered with paraffin paper bags and those uncovered gave about tle same degree of fertility. When we show the degree in question by the mean of the values Found by these two methods of investigation in cach varicty, it was $79.6 \%$ on the average, the minimum and the maximum being osio \% an $185.5 \%$ respectively. Jutging from the fact that the riscrepancy between the two extrence is relatively small, the degree of fertility in the parent varietics suffertilized, no matter how different they are morpholegically in their native places, is about the same in both and seems to be pretly lighl (see Table II).

2) Fertility of the $F^{*}$, plants within the same type and of those between the different types

The investigation of $39 \mathrm{~F}{ }_{\mathrm{r}}$-hybrids, which were atificially produced from any two of them, taken at random out of the 9 varieties of the "Japonica" type (Vase-Shimriki, Nakate-Shinriki, Schiyana, Omachi, Hiderishirazu, Tataso, Chan-shou-wan-1ao, Chang-shuo-chen-ni, and IIsiang-tao) on the one hand, and the 2 varieties of the "Indica" type (Itunan-sien and Tan-ko-fo-ira) on the other, showed that in the 
Table II.

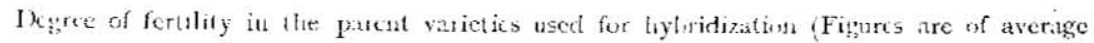
fertibity of 30 intivitials)

\begin{tabular}{|c|c|c|c|c|c|}
\hline \multicolumn{3}{|c|}{ Material usex] } & \multicolumn{3}{|c|}{ Ieegree of fertility $(a, a)$} \\
\hline Type & Sime & $\begin{array}{l}\text { Native } \\
\text { place }\end{array}$ & $\begin{array}{l}\text { Spikes cosered } \\
\text { with paraftis } \\
\text { paper lass }\end{array}$ & $\begin{array}{c}\text { Spikes not } \\
\text { civerid with } \\
\text { parafln } \\
\text { paper Toags }\end{array}$ & Averitge \\
\hline $\begin{array}{r}\text { "Jipenica" } \\
\text { 1ype: }\end{array}$ & Wase-Shinriki & $\begin{array}{l}\text { Japan } \\
\text { I'roper }\end{array}$ & 72.4 & 86.9 & 79.4 \\
\hline$"$ & Nakate-Shinril.i & ', & 79.9 & 85.3 & 82.6 \\
\hline.$\cdot$ & Sekiyama & , & $s_{5.3}$ & $\$ 6.7$ & 86.0 \\
\hline " & ()แlu:hi & $"$ & 76.7 & $\ddot{s} \cdot j$ & 60.0 \\
\hline ", & $\begin{array}{l}\text { Jikkrishirazu } \\
\text { (uplitld tice) }\end{array}$ & $"$ & (it).3 & 64.0 & 82.4 \\
\hline$"$ & Tatabe & Kinre: & 85.6 & $34 \cdot 3$ & 85.0 \\
\hline$"$ & Silpui & $"$ & $6 \% .0$ & $\cdots$ & 68.0 \\
\hline$"$ & Chans sbotr-chtou-mi & Chin & 77.2 & 67.0 & 82,1 \\
\hline " & | Chane shou-wan lan & " & 60.3 & 77.0 & $7 \dot{\prime}, 7$ \\
\hline , & Hsiang tate & $"$ & 68.3 & $\quad 77.6$ & 73.2 \\
\hline "Intica" & Jfunan-sien & China & 66.6 & 73.4 & 70.0 \\
\hline$"$ & $1_{\text {Tan-bor fo-ira }}$ & Forncesia & $36 . ;$ & 86.2 & 86.5 \\
\hline & Average & & 77.4 & 830 & 79.6 \\
\hline
\end{tabular}

hybrids of varicties of the "Japonica" type, the fertility of the crosses within the same type is $48.6 \%$ in minimum, and $83.6 \%$ in maximum, the average being 68.7 \% the parent plants of the same type, grown uncer the same conditions. The same result was obtained in the hybrids between the varieties within the "Indica" type.

The $24 \mathrm{~F}_{1}$ plants resuling from any two varieties belonging to different types taien at random from among the "Japonica" and "Indica" types, gave the following regrees of fertility. The varieties of the "Japonica" typ crossed with those of the "Indica" type showed in theis fertility the minimum $O . I \%$, and the maximum $26.2 \%$, the average being 14. I \%. The varictics of the "Indica" type 
crossed with those of the "Japonica" showed in this respect the minimum $0.0 \%$, and the maximum $334 \%$, the averase being $13.6 \%$. There was a remarkable difference of fertility between the hybrids resulting fiom the different types in both cases, on one hand, and the parent plants grown under the same conditions, on the other.

However, when varieties belonging to the "Japonica" type were hybridized with the Hunan-sien, and the same varieties with the Tanko-fo-ira, the results did not seem to be in complete accord. In the former case, the minimum fertility was $0.1 \%$, the maximum, $13.9 \%$, and the average, $96 \%$, while in the latter, that is, when the Tan-kofo-ira was used for the male plant, the fertility was $10.7 \%, 26.2 \%$ and $\mathrm{s} 7.5 \%$, respectively, which means that the hybrids in the latter case had a somewhat greater fertility. The same phenomena were manifestcd when the Ilunan-sien and Tan-ko-fo-ira were used for the mother plants (Table III).

According to the above results, the $F_{i}$ plants produced by the hybriclization of varicties, belonging to the same type, the "Indica" as well as the "Japonica," show a comparatively high clegree of fertility ; while, on the other hand, those produced by hybriclizing different types appear to show nuch lower fertility.

In orcler to ascertain whether the facts shown by the above $\mathbf{2} 2$ varieties, accordings to the above stated method, would be applicable to other rice varieties, the authors examined 96 other varieties of cultivated rice, incluciing glutinous and non-glutinous varicties, both upland as well as lowland kinds, red rice, and scented rice (all of them have a relatively high degree of fertility) concerning the degree of fertility of the hybrids witlin the same type and in those between the different types. The result showed just as in the case of the 12 varieties that the degree of fertility of the $F_{z}$ plants obtained by means of hybridization of the varieties belonging to the different types, was incleed very small (see Table IV).

3) Degree of the fertility of the $F_{2}$ plants

Basing on the difference of fertility of hybrids of plants within the sme type and those between the different types, the authors have found in the aforesaid experiments that the "Japonica" and "Indica" types, which are two morphological divisions of cultivated rice plants, had a 
Table III.

Fertility of the $\mathbf{F}_{\mathbf{x}}$ plants within the same type and between the different types (Figures indicate the average of from 20 to 50 individuals)

\begin{tabular}{|c|c|c|c|c|c|c|c|c|c|c|c|c|c|c|c|}
\hline \multirow{3}{*}{$\begin{array}{c}\text { Type of } \\
\text { parent } \\
\text { plant }\end{array}$} & \multicolumn{12}{|c|}{ (今) "Japonica" type } & \multicolumn{3}{|c|}{ (0) "Indica" type } \\
\hline & \multicolumn{2}{|c|}{ Name of plant } & $\begin{array}{l}\text { Wase- } \\
\text { Shinriki }\end{array}$ & $\begin{array}{l}\text { Nakate- } \\
\text { Shinriki }\end{array}$ & $\begin{array}{l}\text { Scki- } \\
\text { yama }\end{array}$ & Omachi & \begin{tabular}{|} 
Ifiderishirazu \\
(upland \\
non-glutinous \\
variety) \\
\end{tabular} & Tataso & Salpei & $\begin{array}{l}\text { Chang- } \\
\text { shou- } \\
\text { wan- } \\
\text { tao }\end{array}$ & 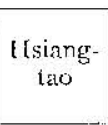 & Average & $\underset{\text { sien }}{\text { Hunan- }}$ & $\begin{array}{c}\text { Tan-ko- } \\
\text { fo-ira }\end{array}$ & Average \\
\hline & & $(\oplus)$ & 79.4 & 82.6 & 86.0 & 80.5 & 82.4 & 35.0 & 63.0 & 73.2 & 78.7 & 79.5 & 70.0 & 86.5 & 78.3 \\
\hline (o) & Wase-Shinrili i & 79.4 & & & 63.3 & & 66.0 & 65.5 & $59 \cdot 5$ & 60.7 & 68.8 & 64.0 & 0.1 & 10.7 & 5.4 \\
\hline \multirow{8}{*}{ "Japonica" } & Sekiyama & 86.0 & 75.7 & 74.2 & & 80.1 & 61.6 & & 82.7 & 62.6 & 74.3 & 73.0 & 8.5 & & 8.5 \\
\hline & Omachi & 80.5 & & & & & & 62.5 & 48.6 & 72.2 & 69.0 & $63 \cdot 1$ & II .6 & 13.9 & 12.8 \\
\hline & $\begin{array}{c}\text { Hiderishirazı } \\
\text { (upland non- }\end{array}$ & $\$ 2.4$ & & & 83.6 & & & & & & 75.0 & 79.3 & 12.6 & 20.2 & 16.4 \\
\hline & Tal aso & 85.0 & 79.9 & & 67.0 & & & & 71.9 & 73.0 & 77.7 & 73.9 & & & \\
\hline & Chang-shou- & 73.2 & & & & & 69.6 & $5 \% 2$ & & & 66.5 & 64.8 & 13.9 & 26.2 & 20.1 \\
\hline & Chang-shou- & $\$ 2 . I$ & & 79.0 & & 62.2 & 53.6 & & & 74.2 & & 67.3 & 8.7 & $2 \mathrm{I} .5$ & 14.6 \\
\hline & IIsiang-tao & $7 \% .7$ & 60.2 & & 60.4 & 75.7 & $54 . \mathrm{I}$ & & & 69.7 & & 64.4 & I 2,1 & 12.6 & I 2.4 \\
\hline & Average & 80.9 & $7 \geq 6$ & 76,6 & 68.6 & 72.7 & 61.0 & 62.1 & $65 \cdot 7$ & 68.7 & $7 \mathrm{r.9}$ & 68.7 & 9.6 & 17.5 & {$[4.1$} \\
\hline \multirow{3}{*}{$\begin{array}{c}(\%) \\
\text { "Indica" } \\
\text { typpe }\end{array}$} & Hunlan-sien & 70.0 & 0.3 & & 8.9 & & $\mathrm{I} 6.2$ & $4 \cdot 5$ & 0.0 & 3.8 & & 5.6 & & 68.7 & 68.7 \\
\hline & Tan-ko-fo-ira & 6.5 & 21.9 & & 33.4 & & & 22.8 & & 19.0 & I 8.4 & 23.1 & $7^{1} \cdot 4$ & & 71.4 \\
\hline & Average & 78.3 & II.I & & 21.2 & & 16.2 & $\mathrm{I} 3.7$ & 0.0 & II .4 & 18.4 & 13.6 & 75.4 & 68.7 & 70.5 \\
\hline
\end{tabular}

(4) Denotes the fertility of the plants by self-fertilization. 
Table IV.

Fertility of the $\mathrm{F}_{2}$ plants obtained from many different varieties of cultivated rice plants

A. Fertility of the bybrids within the same type of the "Japonica"

\begin{tabular}{|c|c|c|c|c|c|c|}
\hline \multicolumn{3}{|c|}{$\begin{array}{l}\text { Vareity of the "Japonica" type } \\
\text { used for the female plant }\end{array}$} & \multicolumn{3}{|c|}{$\begin{array}{c}\text { Variety of the "Japonica" type } \\
\text { used for the male plant }\end{array}$} & \multirow{2}{*}{$\begin{array}{l}\text { Fertility } \\
\text { of the } \mathrm{F}_{\mathrm{t}} \\
\text { plants }\end{array}$} \\
\hline Tame & $\begin{array}{l}\text { Native } \\
\text { place }\end{array}$ & $\begin{array}{c}\text { Fertility } \\
\text { by self- } \\
\text { pollinition }\end{array}$ & Name & Native place & $\begin{array}{c}\text { Fervility } \\
\text { by self- } \\
\text { pollination }\end{array}$ & \\
\hline Wase-Shinriki & Japan & $79.4 \%$ & Jawaij no. $15 \%$ & Ilawaii & $80.0 \%$ & $66.3 \%$ \\
\hline Sekiyama & $"$ & 86.0 & $\begin{array}{r}\text { Chang-shou-chen- } \\
\text { mi }\end{array}$ & China & S2.I & 60.1 \\
\hline$m$ & $"$ & $"$ & $\begin{array}{c}\text { Ilsiao-pê-mang- } \\
\text { shui-tao }\end{array}$ & China (Chili) & 93.7 & 91.6 \\
\hline Aikoku & $"$ & 89.3 & Chans-li & $\begin{array}{c}\text { Clina } \\
\text { (Wuchang) }\end{array}$ & $\delta 6,1$ & 86.7 \\
\hline Hinude & $"$ & 90.6 & Keng-tao & $\begin{array}{l}\text { China } \\
\text { (Changchos) }\end{array}$ & 91.8 & 88.9 \\
\hline " & $"$ & $"$ & Lo-han-huang & China & $9 x .3$ & 74.9 \\
\hline$"$ & $"$ & $"$ & $\begin{array}{l}\text { Keng-tao (Wu-hsi- } \\
\text { lostieh-yen-chiao) }\end{array}$ & China (, ) & 86.8 & 74.9 \\
\hline$"$ & $"$ & , & Ma-tsung-nuto & $"(n)$ & 88.2 & 67.4 \\
\hline$"$ & $"$ & $"$ & Ning-tu &,$\quad(n)$ & 94.1 & 89.1 \\
\hline$"$ & $"$ & $"$ & I Iuo.pe-ku &,$\quad(")$, & 85.2 & 86.2 \\
\hline F Iinomoto & $"$ & 77.3 & $\begin{array}{r}\text { Nanking-hsian- } \\
\text { tao }\end{array}$ & $\left|\begin{array}{l}\text { China } \\
\text { (Tónar Univ.) }\end{array}\right|$ & 86.0 & 83.5 \\
\hline$"$ & $"$ & $"$ & $\begin{array}{r}\text { Sam-li-tsum-muo- } \\
\text { tao }\end{array}$ & China & 83.0 & ßI.4 \\
\hline$"$ & $"$ & $"$ & Nakamura 17 & Formosa & go.8 & 78,2 \\
\hline Ilinode & $"$ & 90.6 & Londuras & T. S. A. & 88.7 & 70.7 \\
\hline$"$ & $"$ & $"$ & Prace no. 6 & $"$ & 81.6 & 70.4 \\
\hline$"$ & $"$ & $"$ & Katete & Brazil & - & 84.0 \\
\hline$"$ & $"$ & $"$ & Anareria & $"$ & 52.2 & 79.1 \\
\hline$"$ & $"$ & $"$ & Buranko & $"$ & 81.7 & $\xi_{3.2}$ \\
\hline Kinen-Mochi & $"$ & $8_{3} .6$ & Okule-Shinriki & Japan & $\delta_{3 \cdot 1}$ & $7+2.2$ \\
\hline$"$ & $"$ & $"$ & Hsiang-tao & China & 76.7 & 70.3 \\
\hline$"$ & $"$ & $"$ & Ilaw:iii no. $15^{8}$ & IJawaii & 50.0 & 78.7 \\
\hline Hawaii no. $5_{53}$ & Hawaii & So.o & Wase-Shinuiki & Japan & 79.4 & 64.3 \\
\hline$"$ & $"$ & $"$ & Seiso & Koreal & 82.0 & 80.2 \\
\hline$"$ & $"$ & $"$ & Flsiang-tan & Cbina & $7 \hat{3} .7$ & 72.4 \\
\hline $\begin{array}{r}\text { Nanking-hsian- } \\
\text { tao }\end{array}$ & China & 77.9 & I Iawaii no, 158 & Hiawaii & 80.0 & 79.1 \\
\hline \multicolumn{2}{|c|}{ Average } & 83.9 & \multicolumn{2}{|c|}{ Average } & 83.6 & 81.2 \\
\hline
\end{tabular}


B. Fertility of the hybrids within the same type of the "Indica"

\begin{tabular}{|c|c|c|c|c|c|c|}
\hline \multicolumn{3}{|c|}{$\begin{array}{l}\text { Variety of the "Indica "type } \\
\text { used for the female plant }\end{array}$} & \multicolumn{3}{|c|}{$\begin{array}{l}\text { Variety of the " Indica" type used } \\
\text { for the male plant }\end{array}$} & \multirow{2}{*}{$\begin{array}{l}\text { Fertility } \\
\text { of the } \\
F \text {, plants }\end{array}$} \\
\hline Name & $\begin{array}{l}\text { Native } \\
\text { place }\end{array}$ & $\begin{array}{c}\text { lertility } \\
\text { by self- } \\
\text { pollination }\end{array}$ & Name & $\begin{array}{c}\text { Native } \\
\text { place }\end{array}$ & $\begin{array}{l}\text { Fertility } \\
\text { by self- } \\
\text { pollination }\end{array}$ & \\
\hline $\begin{array}{l}\text { Pu-chiamg san- } \\
\text { pe-li-keng-tao } \\
\text { Chiang-nan-tao }\end{array}$ & China & $83.8 \%$ & $\begin{array}{l}\text { (Hang-shou- } \\
\text { sien-tao } \\
\text { Pa-shih-sien }\end{array}$ & China & $85.6 \%$ & $84.9 \%$ \\
\hline \multicolumn{2}{|c|}{ Average } & 87.4 & \multicolumn{2}{|l|}{ Average } & 86.4 & 85.6 \\
\hline
\end{tabular}

C. Fertility of the $F_{x}$ plants between the different types, that is, between the "Japouica" and the "Indica" type

\begin{tabular}{|c|c|c|c|c|c|c|}
\hline \multicolumn{3}{|c|}{$\begin{array}{l}\text { Variety of the "Japonica" wype } \\
\text { used for the female plani }\end{array}$} & \multicolumn{3}{|c|}{$\begin{array}{c}\text { Variety of the "Indica" type used for } \\
\text { the malc plant }\end{array}$} & \multirow{2}{*}{$\begin{array}{l}\text { Fertility } \\
\text { of the } \\
F_{1} \text { plants }\end{array}$} \\
\hline Name & $\begin{array}{l}\text { Native } \\
\text { place }\end{array}$ & $\begin{array}{c}\text { lertiluy } \\
\text { by self- } \\
\text { pollination }\end{array}$ & Name & $\begin{array}{l}\text { Yative } \\
\text { place }\end{array}$ & $\begin{array}{c}\text { lertility } \\
\text { by self- } \\
\text { pollination }\end{array}$ & \\
\hline Okute-Shinriki & Japan & $63.1 \%$ & Tan-ko-fo-ira & Formosa & $86.5 \%$ & $3.0 \%$ \\
\hline Sekiy:ama & ” & 86.0 & Sei-yu & , & 86.0 & 8.8 \\
\hline Hinomets & " & 77.3 & Ela-kokut-fo-ira & ", & 742 & 0.7 \\
\hline Wase-Shinriki & $"$ & 79.4 & $\begin{array}{l}\text { Pu-chiang-san- } \\
\text { pe-li-keng-tao }\end{array}$ & China & 83.8 & 5.5 \\
\hline Nakate-Shinriki & $"$ & 82.6 & Fung-ku-fumg-tao & $"$ & $77 \cdot 2$ & I. 8 \\
\hline Sekiyama & " & 86,0 & $\begin{array}{l}\text { Gu-shilh-jilh- } \\
\text { sten-tas }\end{array}$ & $\begin{array}{l}\text { Chirra } \\
\text { (Cheliang) }\end{array}$ & 80.5 & 24.7 \\
\hline$"$ & $"$ & 86.0 & Jung-hê-tan & $\begin{array}{l}\text { Clnina } \\
\text { (Kiangsu) }\end{array}$ & 72.6 & 13.2 \\
\hline Aikroku & , & 69.3 & Fung-ku-fung-tio & $\begin{array}{l}\text { China } \\
\text { (Chekiang) }\end{array}$ & 77.9 & $\mathrm{I} 0.6$ \\
\hline " & $"$ & 69.3 & Ya-i-tao & $"(")$ & 91.9 & I. I \\
\hline Kameji & , & 90.7 & $\begin{array}{l}\text { I Isiao-li-fung- } \\
\text { keng-tao }\end{array}$ & $"(n)$ & 76.6 & 0.4 \\
\hline$"$ & $"$ & 90.7 & $\begin{array}{l}\text { Pu-chiang-san- } \\
\text { pe-ti-king-tao }\end{array}$ & $"()$, & 61.6 & $8 \cdot 3$ \\
\hline Hinode & $"$ & 90.6 & $\begin{array}{l}\text { rung-tsuj-yü- } \\
\text { keng-tao }\end{array}$ & $\begin{array}{l}\text { China } \\
\text { (Sizcchwan) }\end{array}$ & 826 & 0.5 \\
\hline , & " & 90.6 & $\begin{array}{l}\text { Ping-yang-pé- } \\
\text { sien tao }\end{array}$ & $\begin{array}{l}\text { China } \\
\text { (Chelkiang) }\end{array}$ & 75.9 & 6.5 \\
\hline$"$ & $"$ & 90.6 & $\begin{array}{c}\text { Li-lun-ku- } \\
\text { keugr-1ao }\end{array}$ &,$()$, & 62.5 & 0.5 \\
\hline$"$ & " & 90.6 & $\begin{array}{r}\text { Eluang-pi-king- } \\
\text { tao }\end{array}$ & $"(n)$ & $7 \approx 6$ & 1.6 \\
\hline$"$ & " & 90.6 & $\begin{array}{l}\text { Fên-shui-san- } \\
\text { pé-li-keng-tao }\end{array}$ & $"(n)$ & 71.2 & 13.2 \\
\hline$"$ & " & 90.6 & $\begin{array}{l}\text { Chi-ching-tao- } \\
\text { keng-tao }\end{array}$ & $"(n)$ & 71.1 & 0 \\
\hline$"$ & $"$ & so.6 & Ai-keng-tao & $"(n)$ & 72.5 & o \\
\hline
\end{tabular}




\section{Continued}

\begin{tabular}{|c|c|c|c|c|c|c|}
\hline Hinode & Japan & $406 \%$ & $\underset{\text { Mang-ku-ken }}{\text { tao }}$ & $\begin{array}{l}\text { China } \\
\text { (Cheliang) }\end{array}$ & $\$_{1.4}$ & 0.9 \\
\hline , & $"$ & yo. 6 & Ta-ku-keng-1ao & $" 1,1$ & Sio & 0 \\
\hline , & $"$ & 90.6 & Sien-tao-wa-mci & $\begin{array}{l}\text { Chima } \\
\text { (Kiannsti) }\end{array}$ & sion & 1.4 \\
\hline$"$ & $"$ & yots & Yaug-sien-tan & $"()$, & $76 \cdot 3$ & 1.3 \\
\hline Hincmoto & , & $77 \cdot 3$ & Tao-jen-chiau & Chima & 86.2 & 0 \\
\hline$"$ & , & $77 \cdot 3$ & Chiang nan-lao & $\begin{array}{l}\text { ('hina } \\
\text { (Anwhei) }\end{array}$ & $(6) \ddot{6}$ & $4 \cdots 7$ \\
\hline$"$ & " & $77 \cdot 3$ & 1sao-sicn-tao & $\begin{array}{c}\text { Chinil To. } \\
\text { nan Luivi }\end{array}$ & 86.8 & 0 \\
\hline$"$ & $"$ & $7 ; 3$ & I'a-shilu-tzu-sjen &, 1, & 72.2 & 14 \\
\hline ", & , & $77 \cdot 3$ & 1Juang-kan-sicn & $" 1, \%$ & 67.0 & 2.2 \\
\hline$"$ & ", & $77 \cdot i$ & $\begin{array}{l}\text { Mao-tzu-tou- } \\
\text { sien-tao }\end{array}$ & $\Rightarrow \quad(\quad)$. & 85.7 & n \\
\hline ", & ," & $77 \cdot 3$ & $\begin{array}{l}\text { I u-shilh-jih- } \\
\text { sicn-iao }\end{array}$ & $\begin{array}{l}\text { (hina } \\
\text { (Clieliany) }\end{array}$ & So: & 66 \\
\hline$"$ & $"$ & 773 & fluo-pe keng-tan & $"()$, & $85 \cdot 3$ & 0 \\
\hline$"$ & $"$ & $77 \cdot 3$ & Fung-ku-keng-tan & $, \quad 1,1$ & 65.1 & 0.2 \\
\hline$"$ & $"$ & $77 \cdot 3$ & Wu-pelimkeng tao &,$\quad(,)$, & 60.9 & 0.3 \\
\hline$"$ & ", & 77.3 & $\begin{array}{l}\text { Si ych-tsing- } \\
\text { heng-lao }\end{array}$ & $, \quad \vdots \quad, \quad 1$ & 01.3 & 1.5 \\
\hline Minode & " & go.6 & 1:a-1saceleng-tao &,$\quad(, \quad)$ & 4.0 & $a$ \\
\hline $\begin{array}{l}\text { Yishitakta- } \\
\text { Mtsiloi }\end{array}$ & " & $7 \because \cdots 2$ & $\begin{array}{r}\text { Clamg-ken-wan- } \\
\text { heng-tao }\end{array}$ & (thina & 26.9 & $3 \cdot 3$ \\
\hline 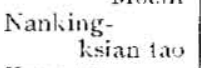 & China & 77.9 & $\begin{array}{l}\text { Mens kan peng- } \\
\text { Jicug-1 ao }\end{array}$ & $"$ & $(4,9$ & $\therefore 7$ \\
\hline $\begin{array}{l}\text { Kerig-taci- } \\
\text { clang-clou }\end{array}$ & $\left|\begin{array}{c}\text { China } \\
\text { (Kiangsu) }\end{array}\right|$ & $9 x .8$ & Kolyatru-fo-ira & Formesta & S. . . & 2.7 \\
\hline , & , & 918 & Cikt)kt-12anshi & " & $8 \mathrm{I} . \mathrm{I}$ & $7+4$ \\
\hline $\begin{array}{l}\text { Nishitaku } \\
\text { Mlochi }\end{array}$ & !apaı & 79.2 & Vellisenalli & Java & 67.5 & $\therefore 4$ \\
\hline Ilinode & $\because$ & 906 & Gangasale Blatta & $\begin{array}{l}\text { Sontliems } \\
\text { Inuliat }\end{array}$ & $55 \cdot 3$ & 0 \\
\hline$"$ & " & 90.6 & Kerl Kangro & $\begin{array}{c}\text { Western } \\
\text { India }\end{array}$ & SI.o & 20.3 \\
\hline Kanteji & $"$ & 90.7 & Scenaddy & (eylon & $78 \%$ & 6.0 \\
\hline Ilinede & $"$ & 90.6 & Karafla cheenati & $"$ & 75.1 & 0 \\
\hline$"$ & $"$ & 906 & Hawaii no. 17 & Heiwaii & - & 29) 9 \\
\hline$"$ & $"$ & 50.6 & Carolina Crild & U.S.A. & 0,6 & 14 \\
\hline $\begin{array}{l}\text { Keng-tar- } \\
\text { chang chos }\end{array}$ & $\begin{array}{l}\text { China } \\
\text { Kiannsui }\end{array}$ & 910 & $"$ & $"$ & 93.6 & 10.2 \\
\hline \multicolumn{2}{|c|}{ Average } & 85.4 & \multicolumn{2}{|l|}{ Average } & 79,8 & 4.7 \\
\hline
\end{tabular}


D. Fertility of the tis plants lotween the difierent types, that is, between the "Indica" and the "Japonica" type

\begin{tabular}{|c|c|c|c|c|c|c|}
\hline \multicolumn{3}{|c|}{$\begin{array}{c}\text { Varicty of the "Indica" type used } \\
\text { for the fentate plant }\end{array}$} & \multicolumn{3}{|c|}{$\begin{array}{l}\text { Variety of the " Jiponica "type } \\
\text { tsed for the nale plant }\end{array}$} & \multirow{2}{*}{$\begin{array}{l}\text { Fertility } \\
\text { of the } \\
\mathrm{F}_{2} \text { plants }\end{array}$} \\
\hline Nane & $\begin{array}{l}\text { Nollive } \\
\text { llace }\end{array}$ & $\begin{array}{c}\text { Derility } \\
\text { by self- } \\
\text { pollination }\end{array}$ & Name & $\begin{array}{l}\text { Native } \\
\text { place }\end{array}$ & $\begin{array}{l}\text { Fertility } \\
\text { ly self- } \\
\text { pollination }\end{array}$ & \\
\hline $\begin{array}{l}\text { ['u-chians-san- } \\
\text { pe-]i-keng-tao }\end{array}$ & $\begin{array}{l}\text { China } \\
\text { (Cluekiang) }\end{array}$ & $83.8 \%$ & Wase Shinriki & Japan & $79.4 \%$ & $3.6 \%$ \\
\hline Frumg-kuffung- $\underset{\text { tao }}{ }$ & 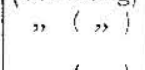 & 77.2 & Nitkite-Shintiki & $"$ & 82.6 & I.9 \\
\hline " & $\Rightarrow 1, j$ & 77.2 & Keng-fao-chang. & $\begin{array}{l}\text { Cluina } \\
\text { (Kiangsul) }\end{array}$ & $92 \cdot 1$ & $2 \cdot 3$ \\
\hline To-lsan-kedses & $=1,1$ & $8_{4} .0$ & Nakinatera 17 & Jurmosa & 90.8 & 0 \\
\hline, & 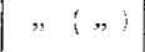 & S.p.o & Fortina & U.SA. & 54.2 & 3.5 \\
\hline$"$ & $, \quad i, y$ & 8... & Texas Fortuma & ", & $8 \mathbf{1} \cdot 5$ & I. 7 \\
\hline Avernes & & 81.7 & Average & & 80.2 & 2.2 \\
\hline
\end{tabular}

very poor sexual affinily. Not satisfied with such results alone, howcver, they self-pollinated the chicf $F_{1}$ pluts of both linds and obtained sects. They examined the fertility of the $F_{2}$ plants in the same manner as in the $F^{2}$, and found that in the $F_{z}$ plants derived from the hybrids between the different types, the lines of various degrees of fertility was segregated out, ranging from a high degree of fertility to absolute sterility, the mean of fertility being $26.2 \%$ in minimum, and $59.9 \%$ in maximum, and $39.9 \%$ on the average. The deviation of fertility in every line was, when the mean is put $100, \pm 39.1$ for the minimum, and \pm 85.9 for the maximum, and \pm 59.7 for the average.

On the other hand, they observed that cvery line produced from hybrids within the same type was very fertile. Taking Tataso $\times$ WaseShinriki and Tan-ko-forira $\times$ IJunan-sion for comparison, they found that the mean of fertility was $87.3 \%$ in the former and $74.4 \%$ in the latter, the average being $80.9 \%$, while the deviation in both cases was only \pm 8.6 , when the mean was 100 . In other words, the $F_{2}$ plants resulting from hybrids between the different types, as compared with those within the same type, were suall as to the mean of fertility, and consequently much greater in deviation (see Table V). 


\section{Table V.}

Fertility and feviation of fertiity of the $F_{2}$ plants deriven from the hybrids between the different types and within the same type

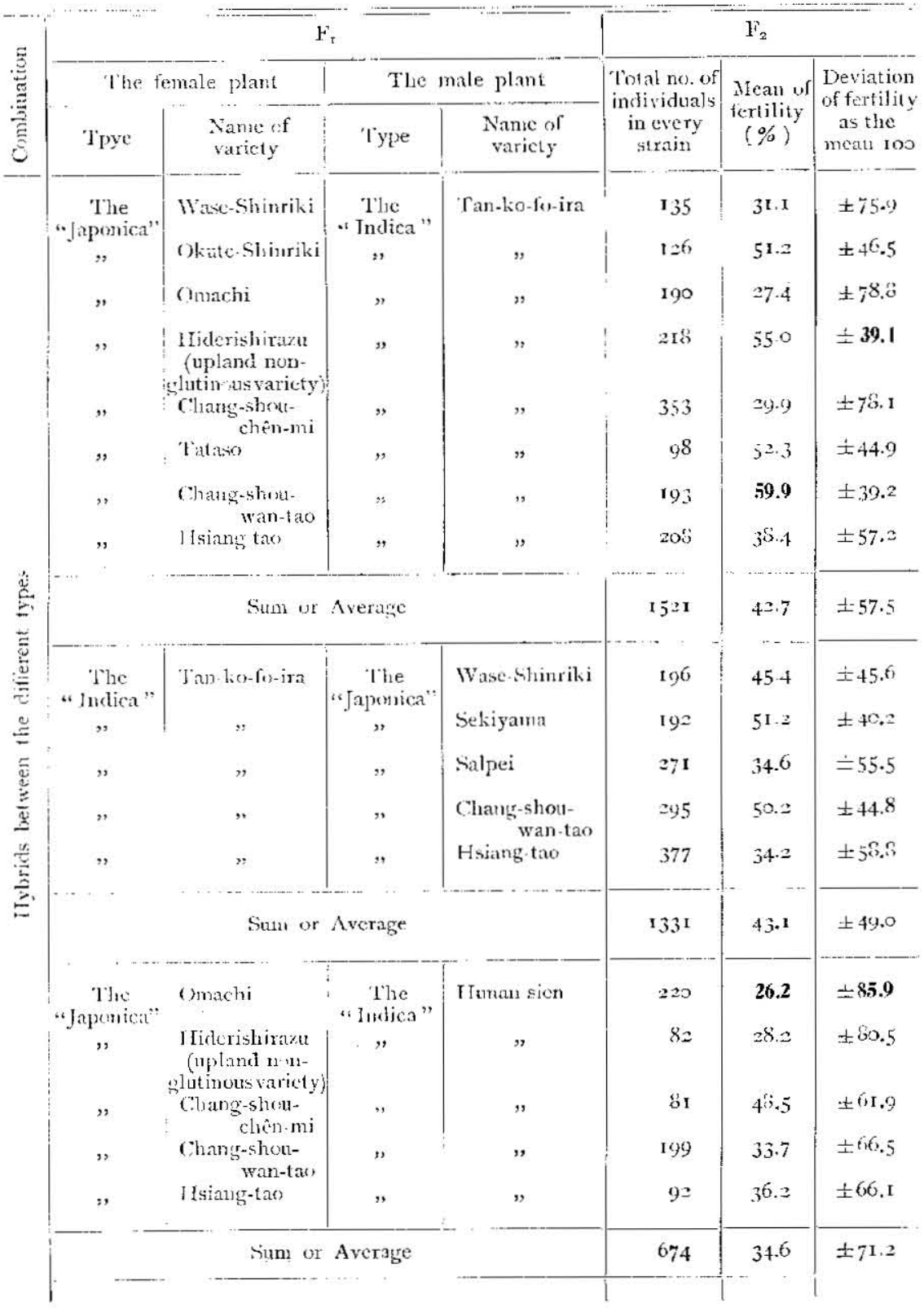


Table V. Cintinued

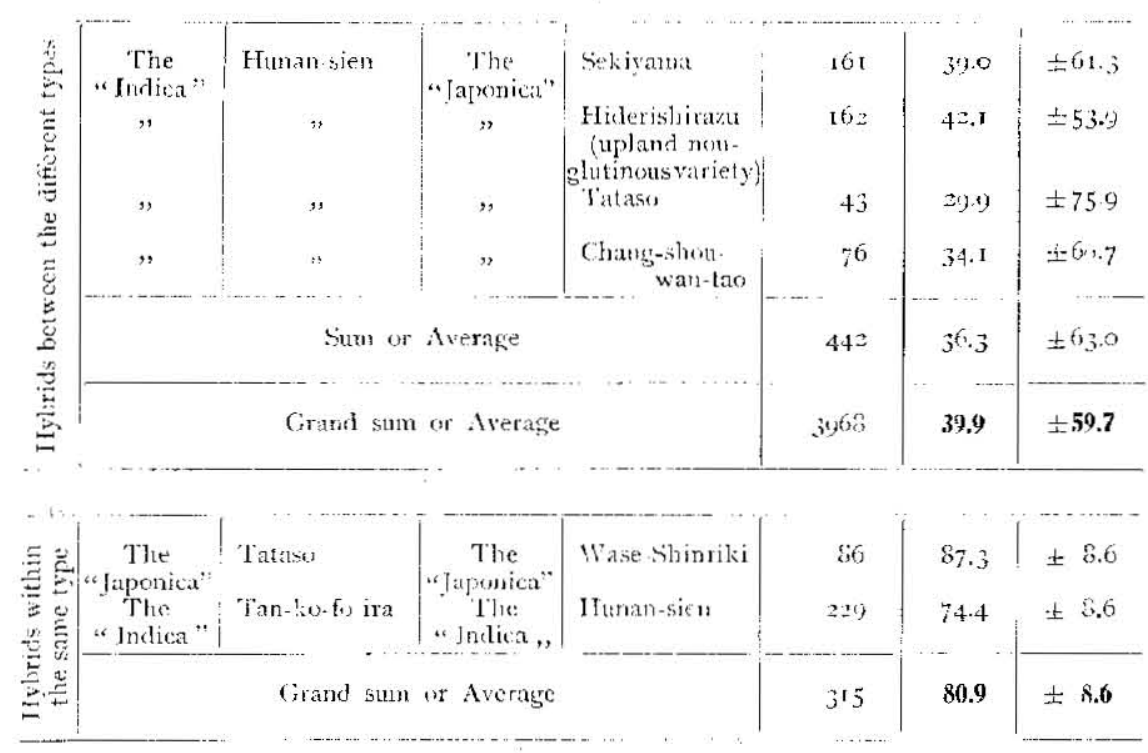

Seemingly, there is also a slight difference in the segregation of degrees of fertility between the hybrids of the different types when the Ilunan-sien is used for a parent and those of the different types when the Tan-ko-fo-ira is used for onc. To speak more: specifically, in the former case, the mean of fertility was $36.3 \%$ ant the deviation, \pm 63.0 on the average, the mean being IOo, when the IIunan-sien was used for the female plant; when it was used for the male plant, the mean of fertility was $346 \%$ and the deviation, $71.2 \quad($ mean $=100$ ). Averaging the above values, we get 35.5 \% for the mean of fertility and $\pm 67 . \mathrm{I}$ for the deviation, the mean being again 100 . In the latter casc, however, the mean of fertility was $43.1 \%$ and the deviation \pm 49.0 when the Tan-ko-fo-ira was used for the fermale plant; when it was used for the male plant, the mean of fertility, $42.7 \%$ and the deviation, \pm 57.5 (mean $=100$ ). Averaging the above values, we get 42.9 is for the mean of fertility, and \pm 53.3 the deviation with the mean Ioo. Judging from these facts, the fertility of the $F_{2}$ plants of the different types, when the Iunan sien is used, seems to be smaller in the mean of fertility and greater in the deviation than that of the $l_{2}$ plants of the different types, when the Tan-ko-fo-ira is used. 


\section{AFFAITY OF TIE VARIETIES OF RICE PLANT'S FROM THE SEROMIAGNOSTIC STANDPOIN}

1. Methods of investigation

For the serodiagnostic investigation fresh materials were always used. They consisted of the principal varieties used in the experinents of fertility, nanely i 2 varietics, from 1) Wase-Shinriki to 12) Tan-kofo-ira. The other additional five varieties were Kuromoro, Choeito, Saigoku-kawachi, Genki-Mochi (these are of the "Japonica" type) and Fung-hsizch-nuo (this is of the "Indica" type). Previous to this investigation on rice, the authors canicd on a conpantive stury with 7 graminaceous crops, viz. rice, Italian millet, Sawa millet, maize, barley, whe.t, and corakan. The authors prepared antigen in the serodiagnostic reaction, following the nucthod of Gorlke (4), and made use of the solution, obtained by extracting their seed powder in physiological salt solution. IIowever, for preparing the solution for the precipitin reaction, they firstly made the protein content uniform according to the MisAo's method (16) and then according to the Kokersu's methol (12), adted normal rabbit serum to get off the pseudo-precipitate which was produced thereby. This solution was used as the precipitinogen.

They used "Ring probe" for precipitin reaction: that is to say, the authors put a certain amount of immune serum into narrow tubes; then to each of these they added a certain amount of the solutions of different concentration degrees which had been made by diluting the above mentioned precipitiogen soiution with the physiological salt solution twice, four times, eight times, and so on then they detemined the strength of the precipitate proluced at the plane of contact. The result of this experintent was shown by the strength of reaction within two hours, and the value was denoted by the figures which indicated the minimum concentration showing the positive reaction. As it is difficult however, by this siniple niethod of precipitio reaction alone to male the obvious distinction of rice varicties, the authors performed in addition IVEKHART's "Abrattigungsterfahren" modified by Misto in the testtube and moreoter Msso's "Absittigungsterfaren" in the living body (I6) for precipitin raction.

\section{2. lixperimental results}

1) Results of investisation on the grasses used for comparative study Before undertaking a serodiagnostic investigation of rice, the authors 
examined, for a comparative study, the affinity of 7 graminaceous crops, all of whish belong to different genera, namely rice, Italian millet, Sawa millet, maize, barley, wheat, corakan, by "Ring probe" with each immune serum. No matter what immune serum might be used, the different genera were easily distinguished from each others. And the result seems to show that rice, Italian millet, Sawa millet, and maize are closely related; that barley and wheat are also intimately related; that the latter are distantly related to the former 4 genera (Table VI).

Table VI.

Precipitin reaction with inunune serum of 7 graminacens creps I

\begin{tabular}{|c|c|c|c|c|c|c|c|}
\hline $\begin{array}{l}\text { Imинune seram } \\
\text { Precipitinogen }\end{array}$ & Anti-rice & $\begin{array}{l}\text { Anti- } \\
\text { italian } \\
\text { millet }\end{array}$ & $\begin{array}{l}\text { Anti- } \\
\text { Sawa } \\
\text { millet }\end{array}$ & $\begin{array}{l}\text { Anti- } \\
\text { maize: }\end{array}$ & $\begin{array}{l}\text { Anti- } \\
\text { harley }\end{array}$ & $\begin{array}{l}\text { Anti } \\
\text { whe:tl }\end{array}$ & $\begin{array}{c}\text { Anti- } \\
\text { corakan }\end{array}$ \\
\hline Rice: Orya satiza 1. & 9 & 3 & 4 & $t$ & 0 & 0 & o \\
\hline $\begin{array}{l}\text { Italian millet : Sotaria } \\
\text { italica Bratvols }\end{array}$ & 2 & 8 & 5 & 3 & 0 & 0 & o \\
\hline $\begin{array}{l}\text { Sawa millet: J'nnicum } \\
\text { Crus-Ginlit } 1 . .\end{array}$ & 2 & 3 & 5 & 2 & o & o & o \\
\hline Maize : $Z$ con mais $\mathbf{L}$ & 2 & 3 & 3 & 6 & o & o & o \\
\hline $\begin{array}{l}\text { Barley: IHunlinm sntianum } \\
\text { Jriss. }\end{array}$ & 0 & o & 0 & 0 & 9 & 5 & 0 \\
\hline $\begin{array}{l}\text { Wheat : Triticum sotionm } \\
\text { LAM. }\end{array}$ & 0 & 0 & 0 & 0 & 6 & $\vdots$ & $\circ$ \\
\hline $\begin{array}{l}\text { Corakan : Eieusine } \\
\text { Corarana CiakTNGR }\end{array}$ & 0 & 0 & o & 0 & 0 & 0 & 9 \\
\hline
\end{tabular}

I The varieties cised in this experinent were as follows: rice, Shinrilsi; Italian mildet, Toranos; Sawa millet, Yamanome 1io. a; maize, I fassalsu; barley, Hizalıachi; wheat, Akadauma.

2) Results of investigation on the rice plants

Thanks to this comparative study, the authors clearly distinguished the graminaceous crops, belonging to different grencra by the ordinary methorl of precipitin reaction with each imnune serum. Tlien, adopting the same method as in this comparative study, they studied the affinity of 6 cultivated varieties of rice which belong to the same species and yet live in different regrions, and which have been distinctly classified morphologically by the method of the fertility of hylurid plants. They included 5 cultivated varieties of the "Japonica" type, Shinriki, Selki- 
yama (these are of Japan Proper), Tataso (Korean), Chang-shou-wan-tao and Chang-shou-chèn-mi (Chinese) and I varicty of the "Indica" type, I Junan-sion (Chinese). In this case, whichever immune serum was employed, it was difficult to clistinguish one from another. On the other hand, when the methods of "Absätigungsverfahren" were uscd, both in the test-tube and in the living body for precipitin reaction, these varicties were clearly distinguishable. The results are shown below:

Experiment 1. Firstly, Slinriki, Omachi, ant Sekiyama, which are common cultivated varieties of lowland rice, in Japan Proper, belonging to the "Japonica" type, were tatien. Secondly, the immune serum of cach variety was made, and to this "Absätigungsverfahren" in the test-tube was applied, and then " Ring probe" for precipitin reaction was tried. The varieties were in this case not distinguishable (Table VII).

\section{Table VII}

P'recipitin reaction by "Absittigungserfahren" $j_{1}$ the test-tutue upon low land varieties of Japan Priper, belonging to the " Japmica" type

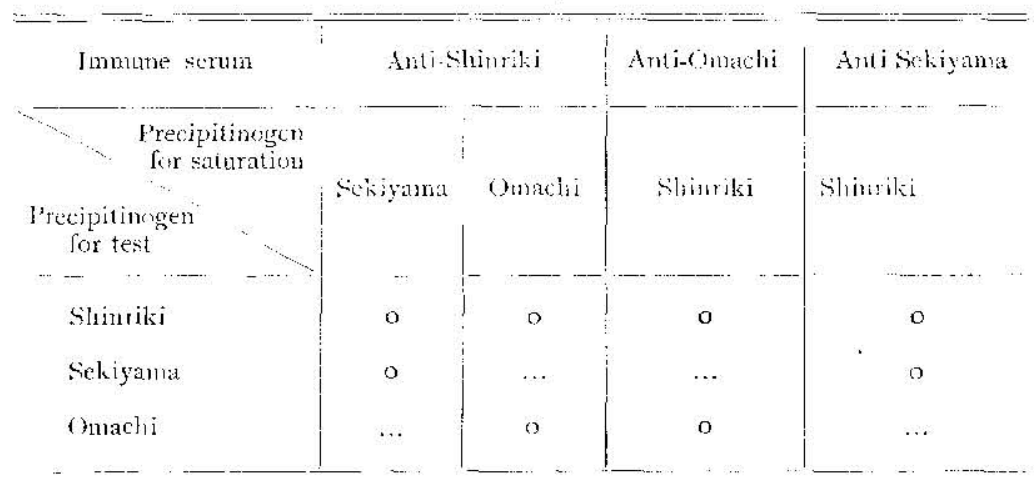

Experiment II. Following the method in experiment I, the authors studied the affinity of 7 varieties of japan Proper, which, like those in the above cxperiment, belong to the "Japonica" type, and which are remarkably difierent from the ordinary cultivated rice from the standpoint of cultivation, use, or grains, viz. Shinriki (a non-glutinous variety), Genki-Mochi (a glatinous variety) (which are lowland rice), Tamasari (a non-glutinous variety), Gifu-Mochi (a glutinous variety) (which are 
lupland rice), long-glumed rice, Kuromoro (red rice), Saigoku-kawachi (scented rice) (which are peculiat kinds of rice). Thic result was that, the Kuromoro and Saigoku-kawachi were barely distinguishable from the others, but the rest was difficult to be distinguisined from one another in this casc (see Table VIII).

Table VIII.

Precipitin reation, by "Absittignnesserfahren" in the test-tulic, of glutineus and nowstlatinon, varieties of lowlun I or uptanel rice or varieties if peculiar rice which are all of Japan l'roper and of llae "Japonica " iype

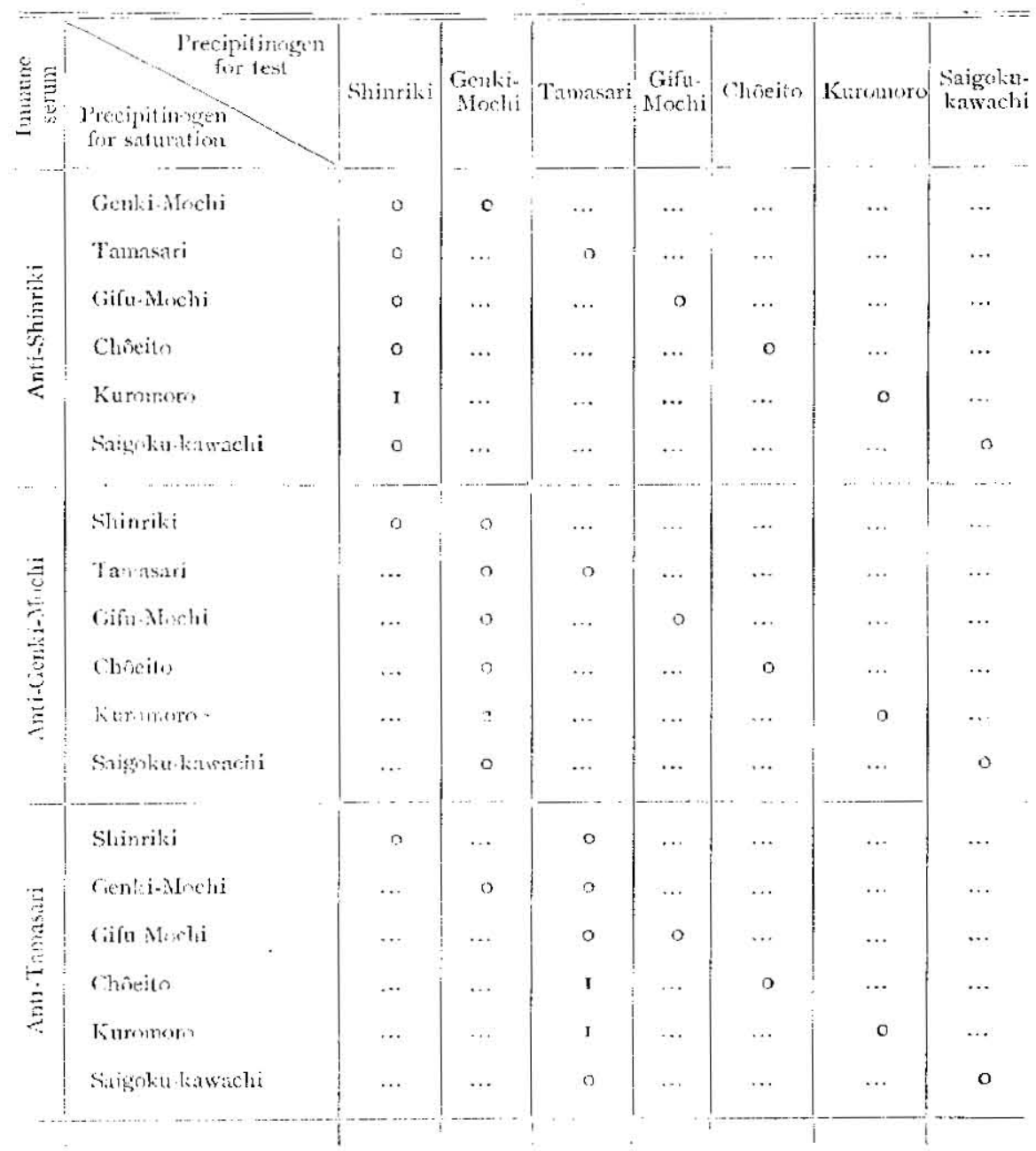


Talsle VIIl Continued

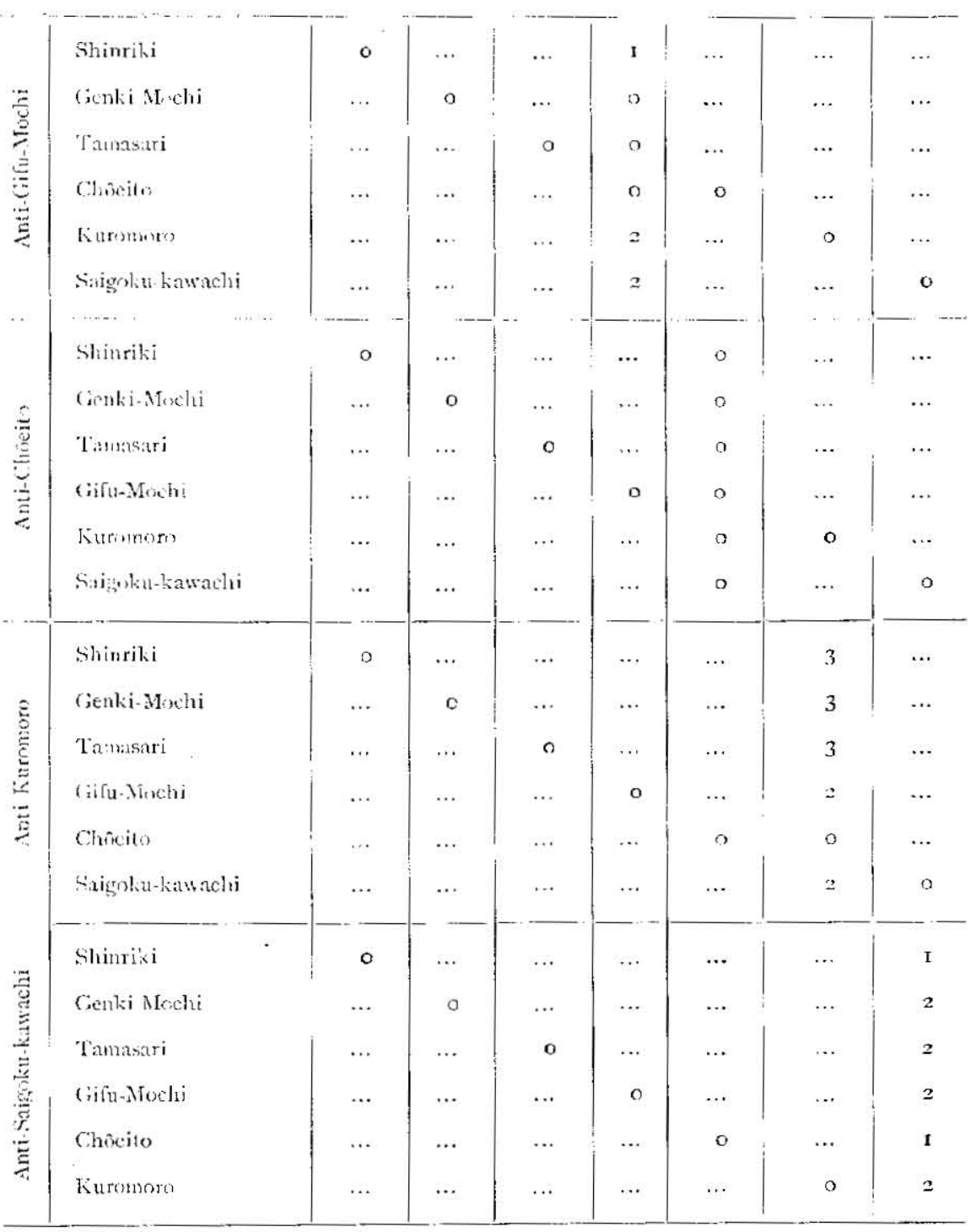

lixperiment IfI. From the morphological standpoint, the following 4 varicties, Shimriki (of Japan Proper), Salpei (Korean), and Changshou-wan-taw (Chinese) of the "Japonica" type and I Iunan-sien (Chinese) of the "Indica" type, were investigated in the manners as described 
in experiment İ. In this case, the above varicties were clearly distinguishable from one another. Taking all facts into consicieration, Shinriki and Chang-shou-wan-tao are related while Hunan-sien is fairly distinct. Salpei, on the other hand, belongs to the "Japonica" type, yet it is also related, according to this experiment, to Hunan-sien of the "Indica" type (sce Table IX)

\section{Table IX.}

Precipitin reaction by" "Alsättigungsverfahrea" in the test fube, of varrotics, bolonging either to the "Japonica" or the "Indica" type, and diffiring in native place

\begin{tabular}{|c|c|c|c|c|c|c|c|c|c|c|c|c|}
\hline Jumthe serum & & $\mathrm{ti-Si}$ & inriki & & ti-s & lpei & & $\begin{array}{c}\text { Ant } \\
112 n !\end{array}$ & $\operatorname{sic} n$ & $\begin{array}{l}\text { Ant } \\
\text { shot }\end{array}$ & $\begin{array}{l}\text { i.Cis } \\
\text { l-W:a }\end{array}$ & ny. \\
\hline $\begin{array}{l}\begin{array}{r}\text { P'recipit } \\
\text { for sat }\end{array} \\
\text { I'recipitingen } \\
\text { for test }\end{array}$ & 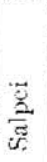 & 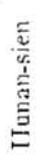 & 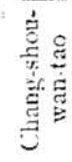 & 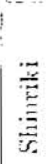 & 离 & 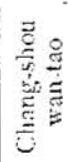 & 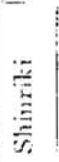 & 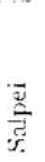 & 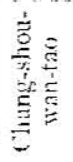 & $\frac{2}{3}$ & $\frac{\vec{z}}{\frac{\vec{z}}{\vec{F}}}$ & 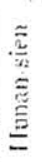 \\
\hline Shinrili & 7 & 5 & 1 & 2 & 0 & I & 2 & I & 2 & $=$ & 6 & 2 \\
\hline Salpei & 2 & I & 4 & 5 & I & 4 & 4 & 2 & 3 & 4 & 2 & 3 \\
\hline IJunan sien & 5 & I & 2 & 5 & o & 4 & 5 & 2 & 4 & 5 & 7 & o \\
\hline Chling-sly u-wan-tan & 7 & 2 & I & 3 & o & 2 & 2 & I & I & 2 & 7 & I \\
\hline
\end{tabular}

Experiment IV. As in the experiment III, the degree of relationship of 7 varieties, Shinriki, Sekiyama, Kinen-Mochi (a glutinous variety), IMderishirazu (upland rice), (all of these are fion Japan l'roper), Tataso (Korean rice), Chang-shou-wan-tao (Chinese rice) belonging to the "Japonica" type and the 'Tan-ko-fo-ira (Formosan rice) belonging to the "Inclica" type, was exumined by using " Ring probe" for precipitin reaction with immune serum obtained by "Abeättingungsverfahren" in the living body of rabbits inmunized with the solution of each of the above varieties. The result was as in the case tried with "Absätingungsverfahren" in the test-tube, ice one could not distinguish Shinriki from Sckiyama, while the other varictics conk be distinguished from one another, though in varying degrees. It was cletermined that Shinriki is closely related to the other varictics of the "Japonica" type, while it is very remotely related to Tan-ko-fo-ira (see Table $\mathrm{X}$ ). 
Table $\mathrm{X}$.

I'recipitin reuction tried "Ansattigungsterfahren" in the living hody with the cultivated varieties of race, faclonging to: the "Japenica" or the "Indlica" fyje

\begin{tabular}{|c|c|c|c|c|c|c|c|c|c|c|c|c|}
\hline I:s:tume serwm & & & Anti- & fimriki & & & Ant- & $\begin{array}{l}\text { Anli- } \\
\text { Iiiticri- } \\
\text { shirazti }\end{array}$ & $\begin{array}{l}\text { Anti- } \\
\text { Kincn- } \\
\text { Nochi }\end{array}$ & $\begin{array}{l}\text { Anti-Tan- } \\
\text { kis-So-ira }\end{array}$ & $\begin{array}{l}\text { Anti } \\
\text { Talaso }\end{array}$ & $\begin{array}{l}\text { Anti-Chang- } \\
\text { shou-win-tan }\end{array}$ \\
\hline $\begin{array}{l}\text { fror saturation } \\
\text { l'recipitinogen } \\
\text { for test }\end{array}$ & -iekiyama & $\begin{array}{l}\text { IIideri } \\
\text { shirazu }\end{array}$ & $\begin{array}{l}\text { Kincn- } \\
\text { Mochi }\end{array}$ & $\begin{array}{c}\text { Tan-ki- } \\
\text { fo ira }\end{array}$ & Tataso & $\begin{array}{l}\text { Chang- } \\
\text { shou-wan- } \\
\text { tao }\end{array}$ & Shinriki & Shinrilii & Shimriki & Slıinriki & Shinuiki & Shinriki \\
\hline Shinriki & 4 & 12 & $\oint$ & $\xi$ & II & 5 & 23 & 8 & 2 & 3 & II & 4 \\
\hline Seliyama & 4 & $\cdots$ & $\cdots$ & $\cdots$ & $\cdots$ & $\cdots$ & 23 & $\cdots$ & $\cdots$ & $\cdots$ & $\ldots$ & $\cdots$ \\
\hline Itiderishirazı & $\cdots$ & I I & $\cdots$ & $\cdots$ & $\cdots$ & $\cdots$ & $\cdots$ & II & $\cdots$ & $\cdots$ & $\cdots$ & . $\cdots$ \\
\hline Kinen Mochi & $\ldots$ & $\ldots$ & 7 & $\ldots$ & $\cdots$ & $\cdots$ & .. & $\ldots$ & + & $\ldots$ & $\cdots$ & $\cdots$ \\
\hline Tan-kofo-fo-ira & $\ldots$ & $\ldots$ & $\ldots$ & 4 & $\cdots$ & $\cdots$ & $\cdots$ & $\ldots$ & $\ldots$ & $s$ & $\ldots$ & $\ldots$ \\
\hline Tatiso & $\ldots$ & $\ldots$ & $\ldots$ & $\ldots$ & 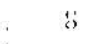 & $\ldots$ & $\ldots$ & $\ldots$ & $\ldots$ & $\ldots$ & 1.5 & $\ldots$ \\
\hline (hang shoul-wan-ta) & $\ldots$ & $\cdots$ & $\cdots$ & $\cdots$ & ... & 4 & $\cdots$ & $\cdots$ & $\cdots$ & $\cdots$ & $\cdots$ & 7 \\
\hline Difference of reaction & 0 & I & t & 4 & 3 & 1 & o & 3 & 2 & 5 & 4 & 3 \\
\hline
\end{tabular}


Table XI.

Precipitin reaction trice "Absättigungsverfahren" in the living body with the cultivated varieties of rice, belonging to the "Japonica" or the "Indica" type

\begin{tabular}{|c|c|c|c|c|c|c|c|c|c|c|c|c|}
\hline Immunc serum & & & Anti-H & mun-sicn & & & $\begin{array}{c}\text { Anti- } \\
\text { Sckiyama }\end{array}$ & $\begin{array}{l}\text { Anti } \\
\text { llideri- } \\
\text { shirazi }\end{array}$ & $\begin{array}{l}\text { Anti } \\
\text { Kineur- } \\
\text { Mochi }\end{array}$ & $\begin{array}{c}\text { Anti-Tan- } \\
\text { ko-fo-ira }\end{array}$ & $\begin{array}{l}\text { Anti- } \\
\text { Tataso }\end{array}$ & $\begin{array}{l}\text { Anti-Chang } \\
\text { shou-wain tao }\end{array}$ \\
\hline $\begin{array}{l}\text { Precipitinogen } \\
\text { for saturation }\end{array}$ & Sekiyama & $\begin{array}{l}\text { IVideri- } \\
\text { shirazu }\end{array}$ & $\begin{array}{l}\text { Kinen- } \\
\text { Mochi }\end{array}$ & $\begin{array}{c}\text { Tan-ho } \\
\text { fo-ira }\end{array}$ & Tataso & $\begin{array}{l}\text { Chang- } \\
\text { shou-wan } \\
\text { tao }\end{array}$ & $\underset{\text { sien }}{\operatorname{Irunan-}}$ & $\left|\begin{array}{c}\text { Hunan } \\
\text { sicu }\end{array}\right|$ & $\begin{array}{c}\text { luman- } \\
\text { sicn }\end{array}$ & $\begin{array}{l}\text { Itunan- } \\
\text { sien }\end{array}$ & $\begin{array}{l}\text { 1 [unan- } \\
\text { sien }\end{array}$ & $\begin{array}{c}\cdot \\
\text { ILunatr-:ient }\end{array}$ \\
\hline IIurau-sien & 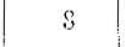 & 15 & 8 & 8 & 12 & 15 & 4 & 5 & i & I & l & II \\
\hline Seliyama & $\mathrm{T}$ & $\cdots$ & $\cdots$ & $\cdots$ & $\cdots$ & $\cdots$ & 15 & $\cdots$ & $\cdots$ & $\cdots$ & $\cdots$ & $\cdots$ \\
\hline 1Niderishirazu & $\ldots$ & 8 & $\ldots$ & $\cdots$ & ... & $\cdots$ & $\cdots$ & 15 & $\cdots$ & $\cdots$ & $\cdots$ & $\cdots$ \\
\hline Kinen-Mochi & $\cdots$ & $\cdots$ & I & $\cdots$ & $\cdots$ & $\cdots$ & $\cdots$ & $\cdots$ & 12 & $\cdots$ & $\cdots$ & $\cdots$ \\
\hline lan ko-.ifora & $\cdots$ & $\cdots$ & $\cdots$ & 4 & $\cdots$ & $\cdots$ & $\cdots$ & $\cdots$ & $\cdots$ & $\delta$ & $\cdots$ & $\cdots$ \\
\hline Tataso & $\cdots$ & $\cdots$ & $\cdots$ & $\cdots$ & 4 & $\cdots$ & $\cdots$ & $\cdots$ & $\cdots$ & $\cdots$ & $\ddot{z}$ & $\cdots$ \\
\hline Chengr-shon-wan-tao & $\cdots$ & $\ldots$ & $\ldots$ & $\cdots$ & $\cdots$ & $\delta$ & $\cdots$ & $\cdots$ & $\cdots$ & $\cdots$ & $\cdots$ & 19 \\
\hline Ditference of reaction & 7 & 7 & 7 & 4 & s & 7 & II & 10 & II & 7 & 7 & 8 \\
\hline
\end{tabular}


lixperiment $V$. As in the experiment IV, the affinity of the undernamed varieties, belonging to the "Japonica" type or the "Indica" type, viz. Selriyama, Ilirlerishirazu (upland rice), Kinur-Mochi (glutinous rice), Tataso, Chang-shou-wantao (the above are of the "Japnia" typ-), Tuma-sien ant Tan-ko-fo-ira (the above are of the "Intica" type), by usiag the immune serum which had been studied by means of "Absattigungsverfahen" in the living body. It was found that the varietics of the "Indica" type were closely related to one another and that they were rather distantly related with those of the "Japonica" type (see Table XI).

According to the above results, the cultivated rice of Japan P'roper, Korca, Formosa, China are more or less distinguishable by "Ring probe" for precipitin reaction, using "Absättingungsverfahren" either in the test-tube or in the living boly. And on the whole, regardless of native regions, the varieties of "Japonica" and "Indlica" types which are morphologically quite distinct appear to be closely related among themselves, while those of the "Japonica" and the "Indica" type seem to be very distantly related.

\section{AHFINITY OF THE VARIETIES OF RICE PLANTS, VIEWED FROM THE CYTOIOGICAL STANHPOINT}

\section{Methods of investigation}

Before conducting a cytological investigation, the authors exanined, as a preliminary experiment, the formation of pollen in $I_{5} F_{2}$ hybrisis, namely $\&$ within the same type and 7 between the different tyles, which were the same as those used for the investigation of fertility, 1hey observed fresh pollen without fixing, and judged the success or failure of pollen development by its form, color, the presence of content, degree of coloration with iodine solution, etc.; to indicate the degree of its success or failure, they cut 1 to 2 anthers from each of 3 to 5 Horets, taken at rantom, from an ear of each plant produced at a comparatively early period, then all pollen grains of each anther were scattered on one slide as evenly as possible, and they counted the percentage of perfect pollen grains as compares with their total number within at certain definite area under the microscope.

As the material for the cytological research, the authors have taken the chief varieties used in the study of fertility and serodiagnostics. 
They are Shinriti, scented rice, Salpei, in the casc of the "Japonica" type; the Ilunan-sien, Fung-hsieh-nuo, and Tan-ko-fo-ina in the case of the "Indica" type. For the exmination of the $F_{1}$ plants, they used, besides the hybrids from these parent plants, the chief hybrids used in the investigation of fertility, making a total of I kinds, that

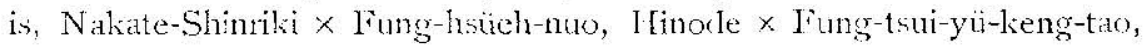
Iinode $\times$ I Iatadavi, I linode $\times$ Basmati, finonoto $\times$ I luo-pe-keng-tao, I linumoto $\times$ l'u-chianc-sang-pe-li-ken-tao, Aikoku $\times$ Tsao-sien-tao, Kameji $\times$ Black Senaddy, I Iunan-sien $\times$ Nakatc-Shinriki, Fung-hsïeh-nuo $x$ Nakate-Shinriki (crusses between the different types), Sei-yu $\times$ Funghasieh-nuo (crosses within the same type).

The authors observed the shape and behavior of the chromosones in the cells of root-tips and in the pollen mother-cells of the parents as well as the $F_{1}$ plants, and furthermore, the general devclopment during pollen formation in the $I^{2}$ plants. For the fixation of the cells of root-tips, they used Fuemancis solution and for that of the pollen mothex-cells, chielly Bocrs's solution, but sometimes Caknor's or Fitumax's solution. The coloration was made with IJemantran's ironalum-hematoxylin. For the observation of the general devclopment luring pollen fomation. the fixation and the coloration wore done as above at its early stages; at the stages later than the formation of tetrads, fresh matcrials wers exdmined, withont fixing. The method used in the determination of pollen development was the same as in the preiminary investigation.

\section{Experimental results}

1) Pollen formation in the $F_{\mathrm{r}}$ plants

In the fertility experiment of hybrids, it has been already found that the $F$, plants within the same type, be it the "Japonica" or the "Indica," are companatively very fertile while those between the different types are markedly infortile. Now the investigations of the formation of pollen in $8 \mathrm{~F}$, plants within the same type and of $7 F_{1}$ ones between the different types, have tanght us that the pollen in hybids within the same type, is nearly perfect; while that between the different types is quite imperfect: imperfect ones are $55.7 \%$ in minimum and of $75.7 \%$ in maximum, the average being $66.1 \%$. The formation of pollon is notably abnormal. 
This being the case, one of the causes of poor fertility of crosses beiween the unlike types may be at least the formation of imperfect pollen (see Table XII).

\section{Table XII.}

Develepmental condition of pollen in the $F_{1}$ plants within the sane type and bolween the different lypes (Figures in the table indicate the aviage value of 3 individuals examined)

\begin{tabular}{|c|c|c|c|c|c|}
\hline \multirow{2}{*}{ 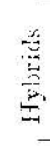 } & \multicolumn{2}{|c|}{ The licmale Plant } & \multicolumn{2}{|c|}{ The Male Flant } & \multirow{2}{*}{$\begin{array}{l}\text { Percentage of itn } \\
\text { perfect ones in the } \\
\text { total number of } \\
\text { follen grains in } \\
\text { the F, plants }\end{array}$} \\
\hline & Type & Name of Variety & Type & Naune of Variety & \\
\hline \multirow{9}{*}{ 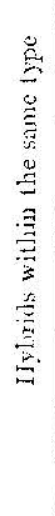 } & "Japonicai" & Wase-Shinriki & "laponica" & IIiderishirazu & 0 \\
\hline & " & $"$ & $"$ & Silpei & 0 \\
\hline & $"$ & Scliyama & $"$ & ()machi & 0 \\
\hline & $"$ & $"$ & $"$ & Chang-shou. & 0 \\
\hline & $"$ & " & $"$ & Chang-shou- & 0 \\
\hline & $"$ & Talaso & , & Silpei & 0 \\
\hline & $"$ & Isia:rg-tao & " & Sckiyama & 0 \\
\hline & $"$ & ; & " & Salpei & $\mathrm{c}$ \\
\hline & \multicolumn{2}{|r|}{ Average } & & & 0 \\
\hline \multirow{8}{*}{ 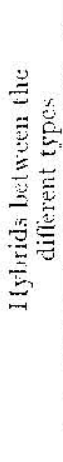 } & "Joperical" & Wate-Shinrihi & " Huslica" & Tin-ko-fu-ira & 65.6 \\
\hline & ” & Omachi & $"$ & $"$ & 55.7 \\
\hline & $"$ & I Tsians-tau & " & $"$ & 71.7 \\
\hline & ", & Nahate-Shinrihi & $"$ & Ifuman sien & 75.7 \\
\hline & $"$ & Seliyana & ", & $"$ & $57 \cdot 3$ \\
\hline & $"$ & Tataso & " & " & 7.3 .9 \\
\hline & "Indica" & Tan-ko-10-ira? & "Japunical" & I Isiang-1au & 62.6 \\
\hline & & Average & & & 66.1 \\
\hline
\end{tabular}




\section{2) Results of cylological research}

The above prelininary investigation of pollen in the $F^{*}$, plants las revealed the fact that the formition of pollen in the hybrids between the different types becones very abnormal. In what stage of pollen formation, then, does this abnomality take place? Is the cause of this abnormality due to the chromosomes of the parent vareties? To answer these questions, the authots made an incuiry into the number and behavior of the chromosomes in the root-tip and the pollen mothercells in the 7 varieties, namcly Nakate-Shinuiki, Okute-Shiniki, scented rice, and Salpei, belonging to the "Japonica" type, and the Ifunan-sien, Fung-hsüeh-nus, and Tan-iso-fo-ina, belonging to the "Indica" type. They foum that the chromosomes were 12 in the haploid and 24 in the diploid number in every one of the varieties, which agrees with the results of previous studies (5, I4, I7). Again, a close examination of the shape and size of the chromosomes has failed to discover any differences among the varieties. Nor have the authors been able to find any irregularity in the behavior of chromosomes in the policn mother-cells and the development of pollen, following the tetsad formation.

The authors then trook the I chicf $F_{i}$ plants out of the liybrids between thee $z$ varieties and those vitricties used in the fentility cxperinent, ic., I hybrid within the same type and to hybrids beiwcen the different types. Then, they examined the number, shape, and behavior of chromosmes in the root-tip and pollen mother-cells in the same manncr as in the parent varieties, and found that in the hyprids within the same lype the points under consideration were essentially the same as in the above mentioned 7 varietics.

On the other hand, in the hybrids between the different tyles, the number and shape of chromosomes and the course up to the formation of the tetrad in the pollen mother-cells-were almost the same as in the hybrials within the same type. There was a great anount of abnomalities in the development of pollen after the tetrad formation. To gro into detal, following the formation of tetarl, each cell which is separated ont from an other, becones round. In this initial stage of growth of the pollen grin, the authors have observed abnormality in the shape of the srain. And moreover at the miclde stage of pollen development, when the growtl of grains alvances further and the content becane visible in them, they not oniy siow that. 
there are some grains of abnormal shape, but also that such grains are never colored with inline solution, and even among those of normal shape, there are a lot of uncolored ones. And at the period when the plants were about to flower, after the full develoment of pollen (the stage of maturity), pollen srains of imperfect shape, those lacking content though nomal in shape, those which were very slightly colned with iodinc solution or those which were thought to be injerfectly developed, were found in great numbers and the degree of imperfect development was approximatcly identical with that at the middle stage. To illustrate this, in the crosses, l Iunan-sien $\times$ Nakate-Shintiki and Fung-hsiich-nuo $\times$ Natrate-Shinriki, the pollen grains of imperfect shape at the initial, middle and maturing stages, ones insufficiently colored with iodine solution, and those which were consides to be imperfectly

- developed, were found on investigation to be as follows:-at the initial

\section{Table XIII.}

Alnimalify in the course of pollen develepment in the $\mathrm{F}$, plants

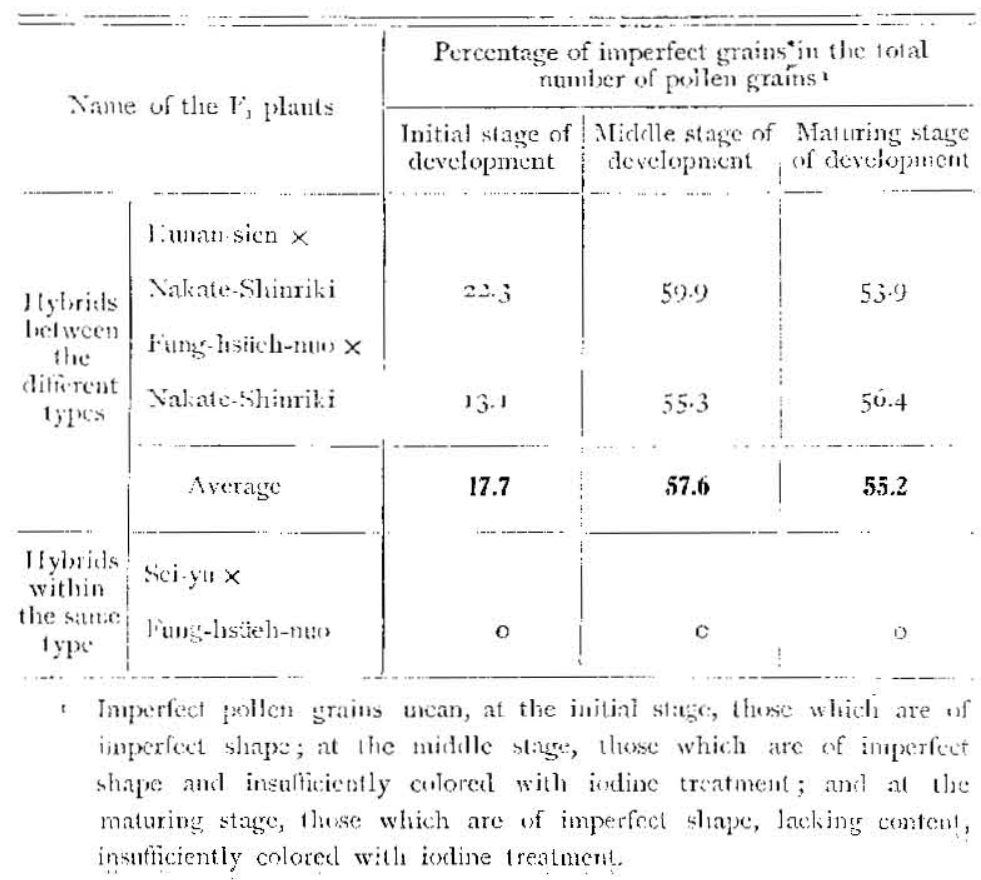


stage, those abnomally shaped were $17.7 \%$; at the middle stage, those inst:fficiently colored with iodine solution, $57.6 \%$; and at the maturing stage, those considered to be incompletely developed, $55.2 \%$ on an average.

I lowever, in the $\mathbf{F}$, plants within the same type (Sci-yu $\times$ Funghsüh-nu, were used for comparative study), we found that imperfect pollen at the initial stage of levekipment amount: to $0.0 \%$, insufficiently colored pollen with iodine treatment at the middle stage $100.0 \%$, and the pollen considered incompletely developed at the maturing stage, aloo to 0.0 \%ó (sec: Table XIII).

These results indicate that there are no differences in the shape, number, and beliavior of chromosomes betwon the "Juponica" and the "Indica" 1ype. This is also true of all kinds of hybrids investigated. Although the course of pollen cievelopment after the tetrad formation is quite nomal in both types and also in the hybrids within the same type, but in the lobrids between the diflerent types abnormality is obscrved soon after the tetrad is formed, and accordingly a great deal of impeffect pollen is to be seen at the maturing period of the poillen.

\section{YI. GENERAL, CONSUIERATION ANI) CONCIUSION}

The above mentioned cultivated varietics of rice may be clasificel into the "Japonica" and "Indica" types from the morpholegical stanclpoint. And the results of experiments on fertility show that there are cortain dilferences between both types, when cven merdy the fertility of the respective $I^{*}$ plants is considered. Indeed, the authors were able to find that the distinction from the morphological standpoint, and that from the derrees of the fertility of the hybrids are in full accorcl.

In spite of the fact that the parent plants are highly self-fertile, the phenomenon of stcrility is witnessed in the $I_{I}$ plants. This is mostly due to the extreme smallness of the sexual affinity, as they are not closely related in descent. In such a case, it is a matter of common knowledge that the formation of pollen in the $F$, plants procecds abnormally ( $1,3,6,7,9$, 10, 19, etc.).

If this is true, then the varieties of the "Japonica" type and those of the "Indica" type could be considered distantly related; on the contrary, in the hybricls within the same type, where we observe a high degree of fertility and normal pollen formation, various varieties 
within either type, conld be regarded as closely related to onc another. Thus, in the $\mathrm{F}_{2}$ generation, the degree of fertility of every hylrid strain within the sane type was great, and was ahmost the same as that of the respective parent, the deviation moreorer beins small. On the other hand, in the hybrids between the two different types, there were various clegrecs of fertility, ranging from absolute sterility to a fairly high degree of fertility, and the deviation was enomousty latge, Jut the mean was smaller than that of the hybrids within the same type. The cause of this may be found in the fact that the varieties of the "Japonica" and those of the "Indica" type need for parents, are not closely alifen. It should be noted here that there is a litte difference in the fertility between the hylrid of the Hunan-sien, belonging to the "Indica" type, with a variety, belonging (o) the "Jakenica" type and tice hyl trid of the Tan-ko-fo-ira with one, belonging to the "Japonica" type; the liybricl resulting from the Tan-hu-fo-ira and a variety of the "Japonica" type is somewhat more fertile than that derived from the Hunan-sien and a varicty of the "Japonica" type linthermore, when segregation occurred in the $F_{2}$ gencration, the $F_{2}$ plants of the one were somewhat great in the mean of fertility, compared with the $F_{2}$ of the other, the deviation being, however, small. This may mean that there is a difference between the two varicties in their affinity with the "Japonica" typc, that is, Tan-ko-fo-ira as compared with IIunan-sien, may justly be regarder as a little more closely allied with the "Japonica" type. This fact may also be recognized from the morphological itandpoint, though Tan-ko-fo-ira bears a close resemblance to Hunan-sicn in the portion of the plant above the ground. The ratio of width to length, thickness to length of the unpolished grain of the 'Tan-ko-fo-ira is comparatively greater than in similar varietics, belonging to the "Japonica" type,-its cross section being roundish.

In their serodiagnostic investigation, the authors used the ordinary "Ring probe" for precipitin reaction to find out the relationship of 7 crops, belonging to different genera of the Ciramineat. And these were clearly distinguishable in different degrees, and the results are in general agreement with the classification of liscilsk and l'KaxtL (2). The authors thinis that this shows serodiagnostic tratunent to be of value to the study of the affinity of the Grominiae. Consequently, they attempted a classification of the cultivated varictics of rice by this treatment. Although they totally failed to do so by the ordinary method of "Ring probc" for precipitin reaction, they could clearly 
differentiate them by "Ring probe" for precipitin reaction with "Absätingungswerfahen" in the test-tube, following Wuichardor (20), or with "Abatitgungsverfahen" in the living boty, following Maso (16). Thi; explantion may be fount in the fact that, thongh the cultivated vatieties of rice being to the same species and have a clowe resemblance anon: themselves, there is probably a far anomint of difference in the nature of proteins contained in their respective grains. Accorting to the result of this investigation, the commonly cultivated varieties of rice of Japan Proper camnot be distinguished at all from cach other. Agan, of the 7 vatieties in Japan Proper used for the principal study which are cifferent from the ordinary cultivated rice from the standpoint of cultivation and use or in the puticular nature of their grains, namely lowland, upland, glutinous, monslutinous, long-shned, scented and red rice, the last two, namely scented and red rice alone were slightly distinct from the other 5 ; but the latter could never be distinguished. Then, the rice varieties lising in different regions, vi\% those of Japan Proper, Korea, Fomrosa, and China, were clearly distinguished from one another in different degrees with " $\mathrm{Ab}$ sättigungsverfahren" either in the test-tube or in the living body. To state specifically ${ }^{\mathrm{I}}$ on the whole, regardless of native places, the varieties, belonging to the "Japonica" type from the morphological standpoint, are allied with one another; those belonging to the "Indica" type are closely rolated to one another; and the varieties of the "Japonica" type and those of the "Indica" type are firily distinct in lescent. This scems to show that the varicties of the "Japonica" and those of the "Indica" type, which are different from the morphological standpoint, are not closely allied.

On comparing the results of the serodiagnostic investigation with those of the fertility cxperiment, the anthos find that the varictics of rice of Japan Proper, Korea, and China, belonging to the "Japonica" type and those of Fomosan and Chinese rice, belonging to the "Indica" type are clearly distinguishable from each other as hybrids. Thus, the fact that this distinction is in general in agreement with the results of the strodiagnostic treatment will justify the classification of cultivated rice into "Japonica" and "Inclica" types.

The authors collected a great many varieties of limland, upland, glutinous, non-glutinous, or red rice from Japan I'ruper, forea, Formosa,

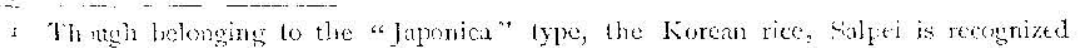

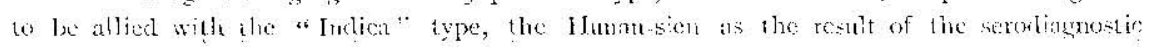
inrestigntion. 
China, Java, India, the United States of America, etc, and tentatively classified them into the "Japonica" and the "Indica" type. Then, carrying on hybridization experiments, they were able to prove that this classification which is made from the morphological standpoint was correct also frem the view point of sexual clishamony of hybrids. Hence, they made inquiry into the native regions of the above varicties, and found that the rice native to Jajan Proper, Korca, and Northern China all belonged to the "Japonica" type and that found in Formosa, Southern China, Java, India, Ceylon, etc, to the "Indica," while some of the varieties in Central Clina, Hawaii, the United States ate of the "Jiponica" and others, of the "Indica" type. These facts may be of significance in the study of the clistribution of the species and varities of rice.

Thanks to the investigation of fertility of hybrids and serodiagnostics, the authors have learned that the two types of cultivated rice classificd morphologically, the "Indica" and the "Japonica" are not closely allied. Again, in the fertility experiments, they have already seen that the formation of pollen in the $F_{1}$ plants between the two different types is markedly abnormal. Jooking over the literature $(5,7,10$, etc.) on this subject, they have noticed that the cause ascribed to the abnomal formation of pollen is either the distant relationship of the parent plants and the dishamony of their chromosones, or the occurrence of abnormality in their pollen development. In the cytological research work upon rice, the authors have found no difference between the varieties of the "Japonica" type and those of the "Indica" type, so far as chromosones are concerned. Nor have they found any difference betwecn the two types in the course of pollen development. This is also true of hybrids within the same type. But in the hybrids between the different types, the authors have seen much pollen which was already abnomal even at the initial stage of its development following the tetrad formation. This may mean that though the distance of the relationship between the two types, the "Japonica" and the "Indica," is not so great that some differences may be obscrved between the behaviors of their chromosomes, these two types are as distantly allied with each other, as there is a physiological difference in the course of pollen development.

In short, the cultivated varieties of rice belonging to the same species are morphologically classified into two groups, the "Japonica" and the "Indica" type; and these are recognized as not closely allied 
with each other in descent from the standpoint of the degrce of sexual alfinity in hybricis and of scrodiagnostic reaction. Consequently, the authors have classified cultivated rice into two groups. They regard them as two subspecies under cultivated rice, Oryas satiza $\mathrm{L}$.; and they propose to call one of them, "Japonica," and the other "Indica."

It has been customary with agronomists ( $\mathrm{II}_{1} \mathrm{I}_{3}$, etc.), when they attempt a classification of cultivated rice, to regard long-glumed, red, and scented rice as being considerably different from the ordinary varietics, putting great weight in the character of grains. However, our investigation shows that all long-glumed varieties produced in Japan Proper belong to the "Japonica" type, showing no difference from the common rice; that red and scented rice which are found both in the "Japonica" and the "Indica" are not markedly different from the ordinary rice; that, though the distinction of glutinous and non-glutinous rice from the standpoint of use is plausible, no difference is found between them, either in the "Japonica" or the "Indica" type ; and that, although rice is Jivided into lowland and upland varieties on account of the different method of cultivation, the upland rice of Japan Proper all belongs to the "Japonica" type and we could not find much difference from the lowland rice.

\section{SUMMARY}

I) According to the morphological stancipoint, the cultivated varieties of rice, including upland, fowland, glatinous, non-glutinous, longglumed, scented, and red rice may be classified into two different types: "Japonica" and "Indica."

2) When cultivated in Japan Propcr, all varicties of both types are highly self-fertile. This is also true of hybrids between varieties which belong to the sane type. On the other hand, the hybrids between varieties belonging to the different types (i.e. "Japonica" and "Indica") are nuch less fertile.

The process of pollen formation in hybrids within the same type and in those between the different types differs very much, in as much as it proceeds nomally in the fomer, while in the latter it is extremely abnermal, the percentage of imperfect pollen grains being markedly great. By cytological examination, it is ascertained that, in the varieties belonging to the "Japonica" and "Indica" types, there is no difference in the number and behavior of their chromosomes, and in the course 
of pollen development. This holds true in the hybrids within the sanc type, but in the liybrids between the different types, the abnumality of pollen is already manifested at the initial stage of its development following the division of the pollen mother-cell.

3) Rice in Japan Proper, Korea, Formosa, and China, belonging to the "Japonica" or "Indica" types can be clcarly differcnitiated in different degrees by "Ring probe" for the precipitin reaction with "Absätigungsverfahen" in the test-tube and in the lising body, generally speaking, the varictics, belonging to the "Japonica" type are closely related as arc those, belonging to the "Indica" type, regardless of where they cone from, while the varieties between the two types are fairly distinct from cacl other.

4) In short, the cultivated varicties of rice are to be classified into the "Japonica" and "Indica" types from the morphological standpoint. Moreover, judging from the degree of the scxual affinity, as well as scrodiagnostic reaction, these two types are considered to be distantly related in descent. Therefore, the authors divide cultivated rice into two groups, regard them as subspecies, and propose to name one "Oryar sativa L. subsp. India KnTo" and the other "Oryaa satiza L. subsp. Japonica KaTo."

5) As to the distribution of subspecies "Japonica" and "Indica" of cultivated rice, we will find that the varicties indigenous to Japan Proper and Korea all belong to the one, and that those native to Formosa as well as those of Solithern China, India, Java, and other conntries mostly belong to the other. Although in Central China rice is, for the most part, of the "Indica" type, some varieties of the "Japonica" type are also found.

The above investigation was carried on in the Collesge of Agriculture, the Imperial University of Kyushu from 1923 to 1928. Durings the investigation, the authors received kind atvices from l'rof. 1)r.

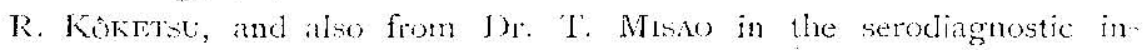
vestigation. To them, the authors tender thanks most gralefully. 


\section{LITERATLRE}

I. ToARwin, C., The Origin of species. Iandon, I9IO.

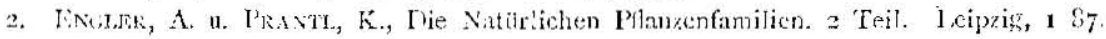

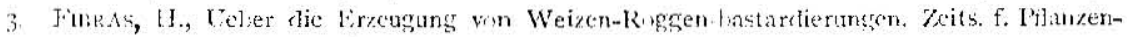
zicht. 7, j) 249, 19zo.

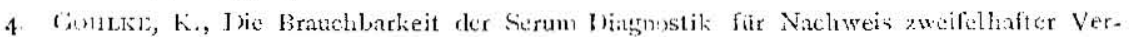

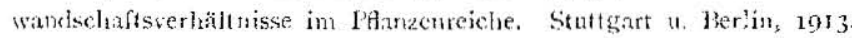

5. Istulsaws, Y., Studies on the inlueritance of sterility in Rice. Jutr. Coll. Agr. Hukkadw Imp. Uni:. 20, P. 79, 1927.

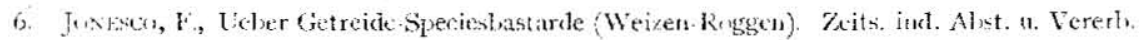
10, p. $311,1913$.

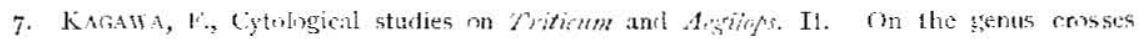

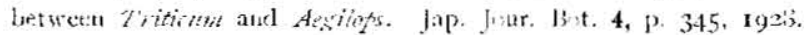

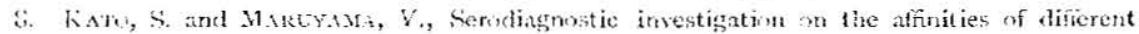
varieties fif rice (in lap.). Rep. l’al. Sci, lakult. Terkolt. Kjus̀ Inp. Lnis. 3, p. 16, I 923 :

9. Kars, S., hisskt, II. and IIAR, S, On the aflinily of rice varicties as shown by the fertitity of layiricl plants (in Jap). Rep. Bal. Sci. Fakult. Terkult. Kjușa Imp. Univ. 3, p. 132,1933 .

Io. Kirnk.1, IL, Cytologische und genctische Studien bei wichtigen Getreidearten mit besonderer Rücksichl auf das Verhalten der Cloromosmmen und die Sterilitit in den Bastarden. Mem:irs Coll. Sci. Kyot: Imp. Univ. Ser. B. I, p. I, 1924.

Ir. Kikknya, S., Ois the classification of cultivated rice. Jour. Coll. Agr. Tnkyo Imp. Liniv. 3, p. I I, 1912 .

12. Tokrtst, R, Serodiagnostische Untersuchungen ibler die Verwandsuhaftsverhälnisse der Ciymnospermen. Mitt. Med. Fakult. Kais. Univ. Kyusinu 4, p. 6r, rọ17.

13. Kökxickt, T., Jlandhuch des Getreidebatas. Berlin, 1835.

14. Kiwaid, Y., A cytolegical study of Oryza setiza. Bust. Mars. Tokyo 24, p. 267, I9to.

15. MFs, C. u. Gounki, K., Physiolegisch-systematiscle Untersuchungen üher die Verwandschaften der Angiospermen. Beitr. Tikol. PHanz. 12, p. 155, 19r3.

16. Musw, 1., Cether die Spezialisierung des Immunscrums und bes. das "Alsättiguntsverfihren in Vivo." luktulka Acta Medica 18, p. 76́o, 1925.

17. Xakatum, S., On the ditference in chromosomes of varieties and the mutant forms in Rice (in Jap.). Jap. Jour. Gen. 2, p. 107, 1923.

38. Schui\%, $\Lambda$, The Geschichte der kultivierten Getreide. I, Yalle I913.

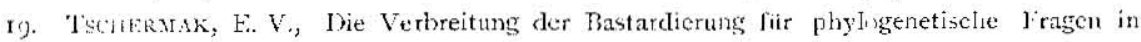
leer Getreide-gruppe. Zeits. f. Plianzenzücht. 2, p. 290, I914.

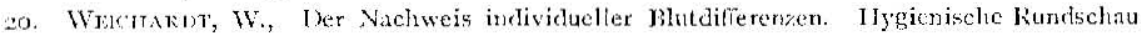
13, p. 765,1903

21. ZAN $\Lambda$, Serologische Studien an feguninnsen und Gramineen. Zeits. f. l'lanzenzuicht. 2, P. IOI, 1914 